\title{
NIEZNOŚNA LEKKOŚĆ POCIESZENIA, NIEZNOŚNA MIAŁKOŚĆ PROTESTU. INTERNETOWE ZMARTWYCHWSTANIA AYLANA KURDIEGO
}

PIOTR JAKUBOWSKI

\author{
Wydział Nauk Humanistycznych Uniwersytetu Kardynała Stefana \\ Wyszyńskiego w Warszawie \\ Faculty of Humanities Cardinal Stefan Wyszyński University in \\ Warsaw (Poland) \\ pjakubowski@ymail.com
}

\begin{abstract}
Poświadczając, że przedmiot był realny, zdjęcie każe podstępnie uwierzyć, $\dot{z} e$ jest on $\dot{z} y w y$ [...]. Fotografia ma $w$ sobie coś wspólnego ze zmartwychwstaniem.
\end{abstract}

Roland Barthes

\section{TRUP JAKO ODNIESIENIE FOTOGRAFII}

Kultura zna trzy modele ciała doskonale nieruchomego: 1. jako rzeźba, posąg, pomnik, figura; 2. jako obraz ciała (malarski, fotograficzny); 3. ciało martwe. Modele te mogą się łączyć, czego przykładem są średniowieczne sarkofagi (tumby) przedstawiające zmarłego spoczywającego na katafalku ${ }^{1}$,

1 W dzisiejszych czasach chce się raczej pamiętać zmarłego jako-żywego, w tym celu na nagrobkach często wykorzystuje się fotografie wykonane za życia osoby zmarłej. Kiedy Roland Barthes ujawniał punctum fotografii Roberta Gardnera Portret Lewisa Payne'a (1865), przedstawiającej niedoszłego mordercę oczekującego na egzekucję, pisał: „on niedługo umrze” (R. Barthes, Światło obrazu, tłum. J. Trznadel, Warszawa 2008, s. 171; zdjęcie Gardnera: s. 169); wspólne punctum osób na fotografiach nagrobkowych brzmi: „Nie wiemy, że już nie żyjemy”; w ten sposób spełniałaby się, inspirowana zresztą Barthes’em („w każdym zdjęciu jest władczy znak naszej przyszłej śmierci”; ibidem, s. 172), uwaga Wojciecha Nowickiego, iż 
jak i fotografie, na których znajdują się zwłoki. Ciało, dotknięte bezwładem śmierci, zostaje tu wtórnie unieruchomione w stałości materii lub pozbawionym czasu przedstawieniu ikonicznym.

Trup jest bytem paradoksalnym - „obecnością, która odsyła do nieobecności”, bliskością oddalenia, wcieleniem nieusuwalnego dystansu („obojętności” - jak powiedziałby Leszek Kołakowski), który dzieli tych, co pozostali, od zmarłego/zmarłej. Przedstawianie trupa oznacza uwiecznienie zmarłego/ zmarłej w jego/jej nieistnieniu, ale jednocześnie ocalenie ciała - w obrazie, w figurze - przed nieuchronnym rozkładem, gdyż zostaje ono niejako zakonserwowane, zachowane $\mathrm{w}$ wyglądzie nieodbiegającym jeszcze od wyglądu ciała żywego, a czasem i w pozycji przez nie przyjmowanej (przykładem są tu niektóre fotografie post mortem czy tak zwane portrety pośmiertne ${ }^{3}$ ).

Fotografia trupa ${ }^{4}$ - podobnie jak dyskurs o nim - służyć ma interesom żyjących. Jedną z najstarszych strategii ludzkich jest próba zachowania zmarłego/zmarłej w krainie żywych, w obrazie lub podobieństwie, by ocalona

każda fotografia przedstawiająca człowieka jest „obrazem osoby in spe martwej” (W. Nowicki, Odbicie, Wołowiec 2015, s. 267). Lęk czy niepokój związany z byciem fotografowanym (vide opowieści etnografów i antropologów o wierzeniach, iż zdjęcie odbiera kawałek duszy) wyartykułował również Barthes, pisząc o „mikrodoświadczeniu śmierci" jako efekcie przemiany podmiotu w przedmiot pod zabiegami fotografa, które określił on zresztą jako „balsamowanie” (fotograf nie tyle więc mnie uśmierca, co objawia i zachowuje mnie jako-trupa, którym już zawsze jestem); analogicznie zresztą odczytał on uczucie dyskomfortu, jakie nawiedza osoby oglądające fotograficzne przedstawienia siebie samych: „widzę, że stałem się Cały-Obrazem, to znaczy ucieleśnioną śmiercią” (R. Barthes, op. cit., s. 29-30).

2 L.-V. Thomas, Trup. Od biologii do antropologii, tłum. K. Kocjan, Łódź 1991, s. 43.

3 Praktyka ta, charakterystyczna dla epoki wiktoriańskiej, powraca współcześnie w ramach powstałego w Stanach Zjednoczonych w roku 2005 terapeutycznego ruchu NILMDTS („Now I Lay Me Down To Sleep” - jest to fragment znanej kołysanki) łączącego psychologów, lekarzy i profesjonalnych fotografów i oferującego rodzicom, którzy stracili dziecko (najczęściej nowo narodzone), upamiętniającą sesję zdjęciową. Zob. www.nowilaymedowntosleep.org [data dostępu: 14.02.16].

4 W kwestii fotografii i śmierci zob. rozdział 49 Światła obrazu (w cytowanym wydaniu na stronach 163-164), a także: A. Linkman, Photography and Death, London 2011. 
została ekspozycyjność właściwa każdej istocie społecznej. Fotografia stanowi tu kolejny etap w ewolucji przedstawień zmarłego, po kukłach, maskach, odlewach, rzeźbach i obrazach ${ }^{5}$. Jak pisze Hans Belting: „Naturalne,

${ }^{5}$ Kiedy „pod strzechy” trafiły już aparaty fotograficzne, a nie wyprowadzono z nich jeszcze ciał zmarłych, panował zwyczaj fotografowania (się) żałobników przy otwartych trumnach, w których spoczywała bliska im osoba. Kilka tego typu fotografii znajduje się w albumach mojego dziadka. Zapytany o nie, odpowiedział, że przyjętą i na wskroś oczywistą praktyką był wówczas zwyczaj wzywania fotografa, gdy ktoś z rodziny umarł. Sam dziadek, kiedy w połowie lat 50 . nabył swój pierwszy aparat - Smienę $80 \mathrm{~m}$ - był kilkakrotnie proszony o wykonanie takich zdjęć u znajomych. Nie potrafił mi jednak udzielić odpowiedzi na pytanie, jaki był tego cel. (Generalnie, na pytanie, po co właściwie robi się zdjęcia, niełatwo jest odpowiedzieć. Ta zarządzająca praktykami oczywistość pozostaje dla świadomości częściowo niezgłębiona). Nowicki uznaje fotografowanie się przy bliskich zmarłych za zsekularyzowany odpowiednik rytuałów konserwacyjnych lub tworzenia odlewów czy masek pośmiertnych: „Najwidoczniej moment śmierci - i dopiero ten moment - wywołuje odruchy pamięci, skurcze mięśnia odpowiedzialnego za magazynowanie obrazów. (Czyżby to przez świadomość, że już nigdy więcej nie będzie okazji?)" (W. Nowicki, op. cit., s. 259). Barthes dodaje tu jednak pewien istotny fakt, który Nowicki, jak się zdaje, przeoczył: nietrwałość, śmiertelność samego zdjęcia. „Dawne społeczeństwa dbały o to, aby wspomnienie, substytut życia, było nieśmiertelne; a przynajmniej aby sama rzecz, wyrażająca śmierć, była nieśmiertelna - to był Pomnik. Czyniąc jednak ze śmiertelnej Fotografii generalnego i jakby naturalnego świadka »tego, co było«, nowoczesne społeczeństwo wyrzekło się pomnika” (R. Barthes, op. cit., s. 166). Wcześniej zaś pisze, iż: „Mogę przekształcić Zdjęcie jedynie w odpadek: albo szuflada, albo kosz" (ibidem, s. 165), co znacząco koresponduje z uwagą Louisa-Vincenta Thomasa dotyczącą traktowania zwłok we współczesnym społeczeństwie: „w kulturze zdominowanej przez ekonomię, gdzie każdego określa się miarą siły roboczej, trup jest oczywiście bezużyteczny, a więc jest odpadem - jak wrak samochodu. Skoro system ten uznaje śmierć tylko technicznie opanowaną, nic więc dziwnego, że praktyki związane z trupami zdumiewająco przypominają operacje wykonywane na śmieciach" (L.-V. Thomas, op. cit., s. 101). Zgoła inaczej na ten fakt zapatruje się Audrey Linkman, który uzasadniając wybór przedmiotu swoich analiz (fotografie obrazujące prywatną stratę, nie zaś ofiary wojen, kataklizmów czy przemocy), pisze: „na tych ilustracjach ciało nie jest ani zaniedbane, ani odrzucone. [...] Fizyczne pozostałości, które były kiedyś żywą osobą, są tu nadal obiektem miłości i troski” (A. Linkman, op. cit., s. 7; jeśli 
śmiertelne ciało, scedowało reprezentację na ciało obrazu, można tė̇ jednak powiedzieć, że ciało obrazu zmonopolizowało obraz osoby, który wraz $\mathrm{z}$ rozpadem naturalnego ciała pozbawiony został żywego nośnika"6.

Druga strategia związana jest ściśle $\mathrm{z}$ „ikonografią cierpienia” i przedstawia ciało martwe w wyniku doznanej przemocy lub masę bezimiennych ciał (przestrzenie „usłane trupami”, krajobrazy, gdzie „trup ściele się gęsto”), lub już-zaraz-trupy (sceny tortur i egzekucji) albo omal-nie-trupy (okaleczone, zmaltretowane ciała jeszcze żywych, walczących o życie). Celem tego typu przedstawień - a przynajmniej ich twórców - jest uwrażliwienie na krzywdę innych ludzi i odstręczenie od zła7. Przez wieki jedyne ciała, które były w ten sposób obrazowane, to (ziemskie) ciało Chrystusa oraz ciała świętych męczenników (ewentualnie ciała wrogów, niewiernych, na triumfalnych przedstawieniach batalistycznych ${ }^{8}$ ). Przedstawienia te jednak jak pisze Susan Sontag - „znajdują się poza zasięgiem żalu czy sprzeciwu

nie zaznaczono inaczej, tłumaczenia z języka angielskiego pochodzą od autora tekstu).

${ }^{6}$ H. Belting, Obraz ciała jako obraz człowieka, [w:] idem, Antropologia obrazu. Szkice do nauki o obrazie, tłum. M. Bryl, Kraków 2007, s. 124 (kursywa oryginalna).

7 O dyskursach usprawiedliwiających przedstawianie cierpienia i okrucieństwa pisałem w tekście O dobrej literaturze („Zeszyty Naukowe Centrum Badań im. Edyty Stein" 2015, nr 13/14, Fenomen dobra, red. A. Grzegorczyk, P. Jakubowski; wersja on-line tekstu: www.academia.edu/19189060/O_dobrej_literaturze). Zob. też: A. Draguła, Flirt z sadyzmem? O fotografowaniu i ogladaniu okrucieństwa, „Więź” 2015, nr 2(660). Oczywiście, najważniejszym tekstem podejmującym to zagadnienie pozostaje Widok cudzego cierpienia Susan Sontag.

8 Tego typu przedstawienia powracają obecnie wraz z praktyką upubliczniania zdjęć ciał - domniemanych bądź nie - terrorystów, których udało się namierzyć i zgładzić, zanim dopuścili się (kolejnych) zbrodni. Arjun Appadurai wskazuje, że przedstawienia te cechuje logika samospełniającej się przepowiedni: „zarówno przemoc wobec terrorystów wspierana przez państwo, jak i lokalna przemoc przeciwko etnicznym sąsiadom zbiegają się w publicznym pokazie schwytanego, zranionego lub upokorzonego ciała wroga jako dowodu tej samej zdrady, którą przemoc miała zniszczyć. W spoczynku śmierci, w bezruchu poddania się ciała terrorystów stają się niemymi pomnikami wroga wewnętrznego, dowodem zdrady w całej jej żałosnej pospolitości”. A. Appadurai, Strach przed mniejszościami. Esej o geografii gniewu, tłum. M. Bucholc, Warszawa 2009, s. 108. 
[...]. Praktyka przedstawiania okrutnych cierpień jako czegoś, nad czym należy ubolewać i czemu trzeba w miarę możliwości położyć kres, wkracza do historii obrazów ze specyficznym tematem: cierpieniami zadawanymi ludności cywilnej przez zwycięską armię w bitewnym szale"'. Wraz ze słynnym cyklem Francisco Goi Okropności wojny wypracowany zostaje „nowy standard reakcji na cierpienie”. A raczej - nowy standard pożqdanej reakcji, gdyż ani twórca obrazu, ani tym bardziej sam obraz nie mają mocy zdeterminowania tego, jaki użytek będzie się z niego robić oraz jakiej odpowiedzi (emocjonalnej, fizjologicznej, ideologicznej) udzielą nań odbiorcy (jeśli w ogóle udzielą - obojętność jest wszak reakcją niepożądaną) ${ }^{10}$.

Sontag w swoim eseju prześledziła historię i meandry przedstawień okrucieństwa oraz dyskursów, które je otaczają, począwszy od przekonania, iż "gdyby dało się potworność wojny ukazać dostatecznie wyraziście, większość ludzi w końcu pojęłaby, jak oburzająca i szaleńcza jest wojna”"11, przez "pornografię cierpienia”"12, po ogólną znieczulicę tych wszystkich, którzy

9 S. Sontag, Widok cudzego cierpienia, tłum. S. Magala, Kraków 2010, s. 52 i 54 .

10 Można wymienić jeszcze dwie strategie: 3) policyjną lub detektywistyczną, związaną z fotograficznym dokumentowaniem miejsc zbrodni w celu prowadzenia śledztwa i gromadzenia materiału dowodowego (trup, podobnie jak w przypadku autopsji, praktyk koronerskich czy anatomopatologicznych, zyskuje tu pewną, paradoksalną, podmiotowość w akcie pełnego uprzedmiotowienia: ma „opowiedzieć" historię ostatnich chwil zmarłego), oraz 4) artystyczną, w którym trup staje się obiektem estetycznym. Historię artystycznego fotografowania ciał zmarłych przedstawia Audrey Linkeman w trzecim rozdziale książki Photography and Death, począwszy od fotografów, którzy tworzyli swe serie w kostnicach, wykorzystując anonimowych „denatów” (Jeffrey Silverthorne, Hans Danusen, Rudolf Schäffer, Andrea Serrano, Joel Peter Witkin), przez artystów związanych z amerykańską kontrkulturą i undergroundową bohemą w epoce, w której swe „żniwo” zaczął zbierać wirus HIV (Nan Goldin, Peter Hujar, David Wojnarowicz), skończywszy na tych twórcach, którym fotografia służyła do wyartykułowania prywatnej straty i przepracowania żałoby (Richard Avedon, Anne Leibovitz, Anne Noble, Briony Campbell, Ishiushi Miyako).

11 S. Sontag, op. cit., s. 21.

12 Sama Sontag nie używa tego określenia, choć jest ono jej przypisywane; można je jednak wyprowadzić $\mathrm{z}$ fragmentu, w którym pisze, iż „apetyt na obrazy 
dzień w dzień, usadowieni w swojej wygodnej pozycji „tych, których to nie dotyczy", konsumują solidną dawkę makabrycznych obrazów płynących z gazet i telewizji, reagując co najwyżej ulotnym i jałowym westchnieniem współczucia. Dyskusje nad zasadnością przedstawiania „widoków cudzego cierpienia” wybuchają co jakiś czas przy okazji opublikowania kolejnego „szokującego materiału”, najczęściej przez tak zwane tabloidy ${ }^{13}$, i równie szybko gasną. Oskarżyciele mówią wówczas o pogwałceniu standardów etyki czy zwykłej przyzwoitości ludzkiej, zhańbieniu elementarnej godności człowieka i jego śmierci, nieliczeniu się z uczuciami bliskich ofiary, wreszcie szukaniu taniej sensacji kosztem życia ludzkiego („żerowaniu” na czyjejś śmierci). Obrońcy - najczęściej przedstawiciele inkryminowanych pism z kolei dowodzą pozytywnych skutków tego typu praktyk, odwołując się do wspomnianych wcześniej narracji uwrażliwienia na krzywdę innych i odstręczenia od zła i okrucieństwa.

Dwie przedstawione wcześniej strategie - ocalenie zmarłego in effigie i „widok cudzego cierpienia” - na swój sposób pozycjonują trupa, osadzając go w sferze prywatnej lub publicznej, czyniąc z niego osobę lub symbol i uderzając w rejestr żałoby lub winy. Do tego podziału zdaje się odwoływać Wojciech Nowicki, gdy w odniesieniu do fotografii przedstawiającej zabitego żołnierza z czasów I wojny światowej pisze - z niejaką pychą - „Ja raczej na

przedstawiające ciała umęczone jest prawie tak silny jak na wizerunki ciał nagich" (ibidem, s. 52). Luis-Vincent Thomas mówi przy tej okazji o „kanibalizmie oka”: „media chętnie wydają na pożarcie pozbawionym dramatów masom najbardziej sensacyjnej obrazy trupów” (L.-V. Thomsas, op. cit., s. 109).

13 Ostatnią okazją ku temu była okładka „Faktu” z 20 sierpnia 2015 roku, przedstawiająca przerażoną i zakrwawioną dziesięcioletnią dziewczynkę, zaatakowaną siekierą przed wejściem do księgarni w Kamiennej Górze. Tekst na okładce brzmi: „Dziewczynka patrzy wielkimi, przerażonymi oczami - przed chwilą szaleniec zaatakował ją siekierą w samym środku miasta. Bestia spokojnie stoi obok, jakby nic się nie stało. Nie szarpie się, nie ucieka. A przecież przed chwilą siekierą rozłupał główkę niewinnego dziecka! Kilka godzin później 10-letnia Kamila zmarła [...]. Śpij słodko, aniołku, tylko Bóg wie, czemu tak się stało". Przytaczam tu ten fragment jedynie po to, by wskazać na przejście jadowitego protestu („bestia”, „rozłupał główkę niewinnego dziecka”) w jałowe pocieszenie („śpij słodko, aniołku”), które interesować mnie będzie w niniejszym tekście. 
ciało patrzę, nie na polityczne przyczyny śmierci"14 . Te dwie optyki mogą ulegać wzajemnej konwersji. Przypadek pierwszy: oto trzech mężczyzn na czele tłumu, każdy z nich trzyma zwłoki dziecka owinięte w wyblakłoczerwone gdzieniegdzie - jakby od rozcieńczonej krwi - płótno; czytam: „krewni niosą ciała ofiar nalotów izraelskich na Beith Gahia (północna strefy Gazy)”. To, co wyraża twarz mężczyzn, najlepiej oddaje biblijne słowo „lamentacje” (jest w tym i gniew, i ból). Martwe dzieci (ich dzieci) są tu ciosem, są wyrzutem winy, ucieleśnieniem żalu i nienawiści wymierzonym w stronę agresorów. Przypadek drugi: oto trzyletni John Fitzgerald Kennedy Jr niezdarnie salutuje przed trumną swojego ojca przejeżdżającą na wojskowym przodku w towarzystwie kompanii honorowej.

Przeciwnicy medialnego upubliczniania obrazów krzywdy i okrucieństwa zdają się podważać równoważność tych planów, wskazując - bez wątpienia słusznie - że aspekt publiczny jest wtórny wobec prywatnego, że każda przedstawiona na nich osoba jest przede wszystkim czyimś dzieckiem lub matką, lub ojcem itd., i to jej bliscy mają pierwotne i niezbywalne prawo tak do jej ciała, jak i jego obrazu, prawo do prywatności żałoby, które to prawo pogwałcone zostaje przez polityczne czy symboliczne wyzyskanie obrazu zmarłego. Co jednak, gdy bliscy sami włączają się w spektakl przedstawień, którego głównym bohaterem jest ciało ich krewnego? Czy pornografii trupa nie towarzyszy czasem ekshibicjonizm żałoby? ${ }^{15}$

Nie zamierzam kontynuować tego wątku ni wpisywać się w żadną z powyższych, przebrzmiałych już nieco, retoryk. Zamiast tego chciałbym, w ramach case study, prześledzić losy pewnej fotografii wykonanej przez Nilüfer Demir, turecką fotoreporterkę pracującą dla agencji DHA, na początku września 2015 roku. Mówiąc o „losach”, na myśli mam dość specyficzny kontekst, nieznany jeszcze Susan Sontag, a określany mianem kultury konwergencji (convergence culture) czy uczestnictwa (participatory culture), czyli - zgodnie z definicją Henry’ego Jenkinsa - „kultury, w której fani

14 W. Nowicki, op. cit., s. 265.

15 Razem $\mathrm{z}$ fotografią Aylana Kurdi w mediach pojawiły się zdjęcia jego zrozpaczonego ojca z zaczerwienionymi od płaczu oczami i ustami ściśniętymi spazmem bólu. Nie twierdzę bynajmniej, że żal Abdullaha Kurdiego nie był autentyczny, tyle tylko, że w obecności fotoreporterów musiał on nabrać wymiaru spektakularnego (w rozumieniu Deborda) lub mitycznego (w rozumieniu Barthes'a). 
i inni konsumenci zapraszani są do aktywnego uczestnictwa w tworzeniu i redystrybucji nowych treści”'16, w której treści oddolne i odgórne (związane $\mathrm{z}$ władzą, mainstreamowymi mediami, światem biznesu) przenikają się wzajemnie, przezwyciężając hegemonistyczny, scentralizowany model przekazu, co stało się możliwe, odkąd „ludowi” - wcześniejszym konsumentom i biernym odbiorcom - udostępniono narzędzia i infrastrukturę umożliwiającą generowanie przekazów i masowe komunikowanie typu many-to-many.

Fotografia autorstwa Nilüfer Demir była bowiem nie tylko masowo udostępniana - zarówno w mediach tradycyjnych, jak i na portalach społecznościowych typu Facebook czy Twitter - ale i powtarzana w szeregu obrazowych przeróbek, remiksów, parafraz czy nawiązań, stając się zarówno „pamięciowym markerem”, „obrazowym toposem” (określenia Ewy Domańskiej), symbolem czy wizualną metonimią „kryzysu uchodźczego", jak też internetowym viralem, a wreszcie memem. Prześledzenie tych wszystkich form „powtórzeń z różnicą”, z konieczności wybiórcze i skrótowe, pozwoli na napisanie glosy do Sontag, uwzględniające zmianę paradygmatu kulturowego związaną z nowym modelem medialnym Podstawowym instrumentarium wykorzystanym w niniejszej pracy będą narzędzia semiotyki.

\section{NIEZNOŚNA MIAŁKOŚĆ PROTESTU}

\section{RAMY I ZNAKI: TAKTYKI WIZUALNE}

Zacząć należałoby od tego, że są dwie fotografie, dwa ujęcia tego samego obiektu: chłopca, rozpoznanego później jako Aylan Kurdi ${ }^{17}$, trzyletni

${ }^{16}$ H. Jenkins, Kultura konwergencji. Zderzenie starych i nowych mediów, tłum. M. Bernatowicz, M. Filiciak, Warszawa 2007, s. 257.

17 To zindywidualizowanie (które wiązało się też z odnalezieniem wielu innych zdjęć Aylana, uśmiechniętego, grającego w piłkę, przytulającego misia, obejmującego brata, który również zginął w tych samych okolicznościach, podobnie jak matka chłopców) odgrywa tu niebagatelną rolę: pozwala ono - jak stwierdziła amerykańska artystka Nan Goldin, fotografująca swoich przyjaciół umierających na AIDS - „nadać ludzką twarz statystyce” (cyt. za: A. Linkman, op. cit., s. 176). Statystyka nie budzi realnego współczucia i nie wywołuje intensywnego sprzeciwu (100, 200, 1000 osób - wszystko to abstrakcje, które nie różnicują emocji), 
Syryjczyk, etnicznie - Kurd, leżącego na plaży, zaraz przy linii morza, nieopodal tureckiej miejscowości Bodrum. Chłopiec ubrany jest w czerwoną koszulkę z krótkim rękawem (koszulka jest podwinięta, w efekcie czego obnażony zostaje beżowy pasek brzucha) oraz granatowe spodenki sięgające za kolana (kolory są ciemniejsze, gdyż ubrania chłopca są mokre); na stopach ma czarne buty sportowe (być może jest bez skarpetek). Leży na brzuchu z głową zwróconą ku ziemi, przechyloną delikatnie na lewo, i rękoma ułożonymi wzdłuż tułowia, skierowanymi powierzchnią dłoni ku górze. Nogi chłopca są lekko podkurczone, w efekcie czego pośladki są odrobinę wypięte i skierowane w prawo. Jedna fotografia zorientowana jest wertykalnie i przedstawia chłopca od strony stóp, druga - horyzontalnie i wykonana jest $\mathrm{z}$ lewej strony chłopca, około pięć metrów od ciała.

Dwa najbardziej emblematyczne elementy tych fotografii to kolorystyka ubrań i ułożenie ciała chłopca - jest to dość niezdarna, a zarazem urocza w swej niezdarności pozycja przyjmowana przez śpiące dzieci. Pozycja ta jest zarazem dość niepokojąca - troskliwy odruch nakazywałby przechylić głowę chłopca bardziej w lewo lub odwrócić go na prawy bok.

Sen od dawna był podstawowym kulturowym modelem tego, czego nie da się pomyśleć, czyli śmierci - tak też śmierć nazywana jest „wiecznym” czy „wiekuistym” snem. Próba zrozumienia śmierci przez analogię ze snem opiera się na zastąpieniu nieznanego - znanym, nieprzyjemnego zaś - przyjemnym. Sen jednakowoż nie przestaje być - jako element życia - jej przeciwieństwem. Wystarczy odwołać się do „odżywczej”, regeneracyjnej mocy

w przeciwieństwie do jednego człowieka, którego możemy „poznać”. Fakt ten wykorzystał chociażby Steven Spielberg w filmie Lista Schindlera (1993), wyodrębniając z tłumu ofiar jedną dziewczynkę poprzez czerwony płaszczyk (cały film utrzymany jest w czarno-białej konwencji) i pokazując ją w dwóch scenach: najpierw podczas łapanki w getcie, następnie na wózku wywożącym ciała. Analogiczny zabieg można odnaleźć na grafice autorstwa Roberta Taubera Calvo Jimeneza, który wmontował ciało Aylana Kurdiego (niewielkie w stosunku do całości obrazu, umieszczone w nieszczególnie widocznym miejscu - blisko lewego górnego rogu - i jako jedyne utrzymane w kolorze) w fotografię przedstawiającą tłum plażowiczów, którzy poprzez ten zabieg stali się figurami obojętności doskonałej (www.boredpanda. com/mare-nostrum/ [data dostępu: 19.02.16]). 
snu. Mimo iż więc wyłączony jest on z kapitalistycznej logiki produkcji, zasila wspierający ją wymóg witalności.
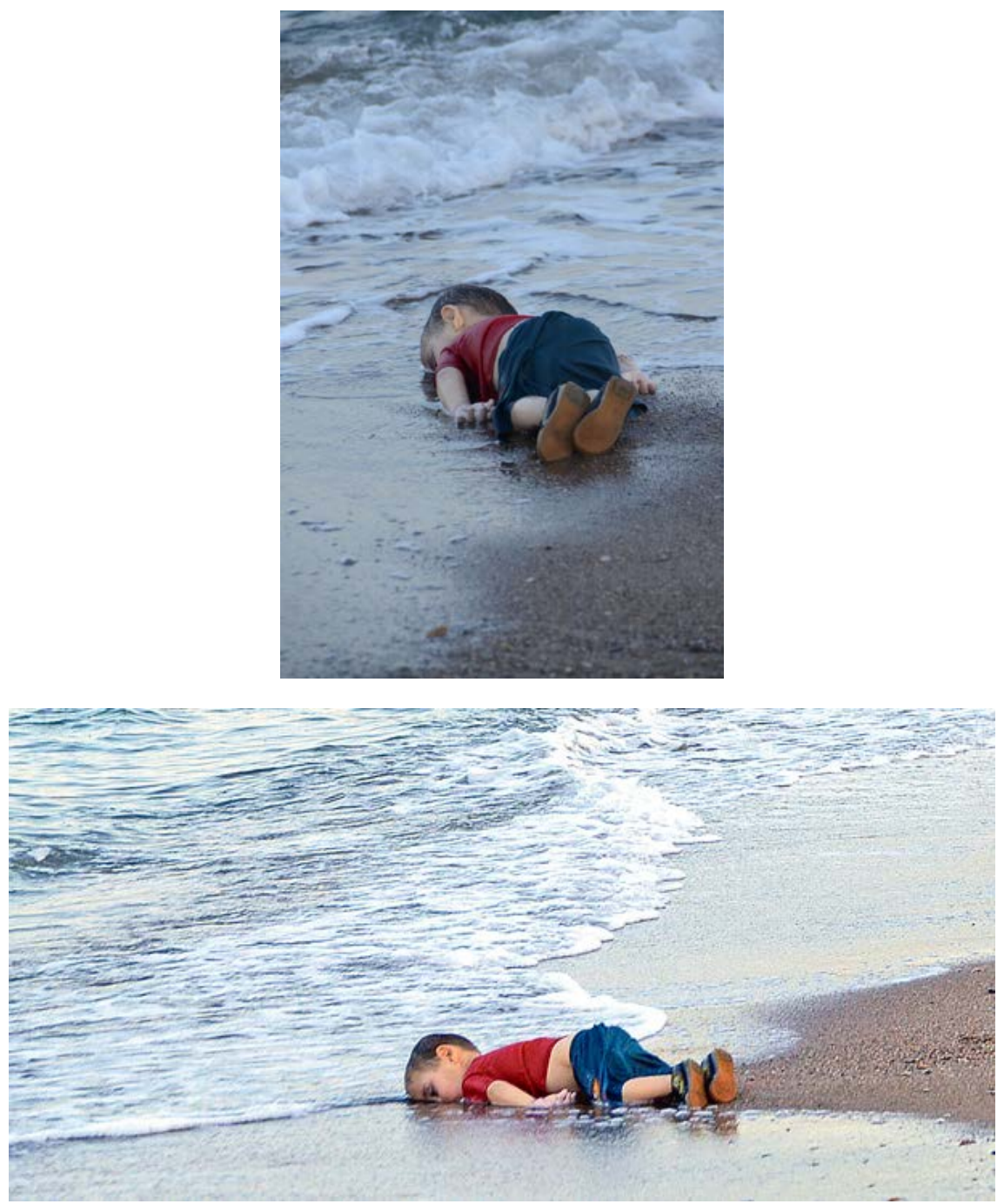

Il. 1 i 2. Aylan Kurdi na plaży w Bordum (fot. Nilüfer Demir/DHA) 
O ile w skazanych na niepowodzenie próbach zrozumienia, czym jest śmierć, co to znaczy / jak to jest nie żyć, sen stanowi analogon śmierci, o tyle na poziomie przedstawień może być jej synonimem: „wygląda, jakby spał/a" - tak czasem, w akcie pocieszenia, opisuje się ciało złożone w trumnie. Szczególnie fotografia, która zamraża oznaki życia obecne w śpiącym ciele - oddech, bicie serca, zmiany pozycji - może spotęgować to wrażenie zmieszania i czasem konfudować („czy fotografia przedstawia osobę śpiącą, czy martwą?”, „która z osób przedstawionych na fotografii nie żyje?”18 - wielu zdjęciom, zwłaszcza dawnym, niemym, pozbawionym podpisu i kontekstu, można te pytania postawić na poważnie i, co więcej, nie umieć na nie odpowiedziećl ${ }^{19}$ ), czasem pocieszać odbiorców: „sen jest niczym słodzik [sweetener], którym powinno się przyozdabiać, a następnie serwować danie, jakim jest śmierć” - pisze Audrey Linkman, i dodaje: „jasnym zamierzeniem portretów typu śmierć-jako-sen jest pocieszanie [comfort] żałobników i dodawanie otuchy [console] tym, którzy pozostali”20.

\section{Taktyka 1: Przeramowanie}

Ciało Aylana Kurdiego na fotografii Nilüfer Demir jest znakiem dwuznacznym, czy nawet przeciwznacznym. Jego znaczenie determinowane jest kontekstem, a właściwie - jako że mowa o obrazie - ramami. Ramy macierzyste nie pozostawiają wątpliwości, że znak-ciało chłopca oznacza śmierć - nikt nie śpi w takiej pozycji w takim miejscu; przypływająca fala obmywa jego twarz, kończąc się na linii ramion (a żywioł wody jest wrogiem snu, w tym

18 To ponownie Roland Barthes wyartykułował ten jednoczesny mankament (epistemologiczny) fotografii i jej (ontologiczny) walor: całkowity triumf istnienia kosztem znaczenia.

19 „Takie właśnie jest zdjęcie: nie umie powiedzieć, co pokazuje” (R. Barthes, op. cit., s. 177). Śladów tej konfuzji można doszukiwać się już w początkach historii fotografii - mam tu na myśli zdjęcie autorstwa Hipolita Bayarda datowane na 18 października 1840 roku, a zatytułowane Autoportret topielca. Fotografia ta przedstawia samego twórcę, który pozował do niej jako-trup w akcie protestu przeciw przyznaniu przez rząd francuski dofinansowania na dalsze badania L.J. Daguerre'owi, a pominięciu Bayarda - wynalazcy alternatywnej techniki, dzięki której na naświetlanym papierze pojawiał się od razu obraz pozytywowy.

20 A. Linkeman, op. cit., s. 21-22. 
wypadku zaś też - wrogiem życia; to ona wszak, uwieczniona na zdjęciu niczym morderca, który nie zdążył uciec z miejsca zbrodni - acz poza rejestrem winy - zabiła chłopca ${ }^{21}$ ). To niezdeterminowanie znaczenia wykorzystali twórcy (prosumenci) przedstawień, w których mamy do czynienia z taktyką określaną jako zmiana ram lub przeramowanie (reframing). Dzięki temu znak, zachowując swą tożsamość na poziomie signifiant, przechodzi w swoje przeciwieństwo na poziomie signifié. Zmiana pola denotacji (śmierć $\rightarrow$ sen) oznacza też zupełnie odmienną płaszczyznę konotacją (nieprzyjemne $\rightarrow$ przyjemne; bolesne $\rightarrow$ urocze; niepokojące $\rightarrow$ spokojne).

Powierzchnia obrazu zdominowana zostaje przez utopijne, kontrrzeczywiste przedstawienie („tak powinno być”), podczas gdy jego negatywne odniesienie („tak jest”) tkwi w reminiscencjach („powidokach”) obrazu pierwotnego i obecne jest poprzez sieć czytelnych nawiązań.

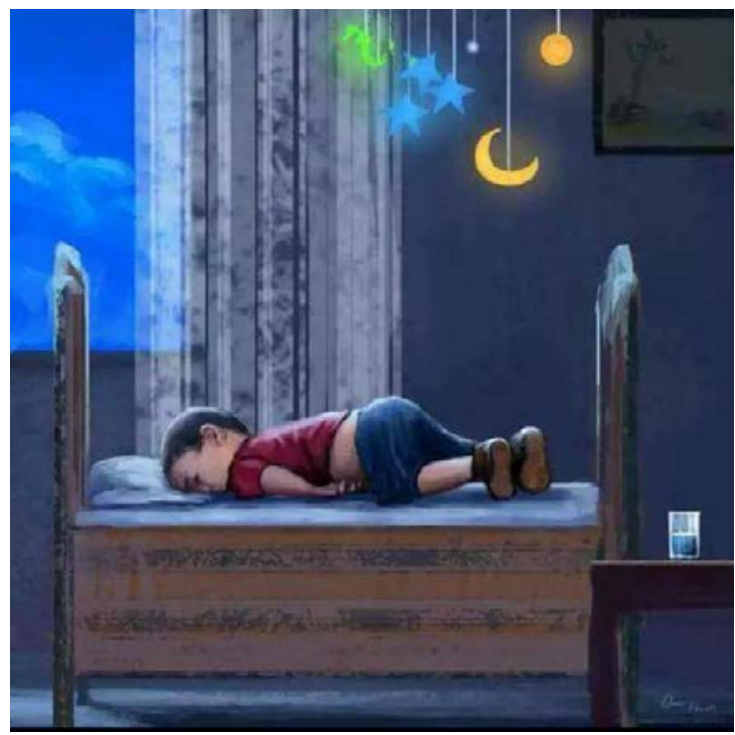

Il. 3. Przeramowanie: grafika autorstwa anonimowego artysty

${ }^{21}$ Audrey Linkman pisze, że na wielu wiktoriańskich fotografiach „przykrywano [overlay] niepokojące wspomnienia bolesnej lub brutalnej śmierci bardziej trwałym i kojącym obrazem spokoju duszy [soul at rest]" (A. Linkman, op. cit., s. 24). Na żadnej ze znanych mi przeróbek fotografii Aylana nie ma nawiązań do 


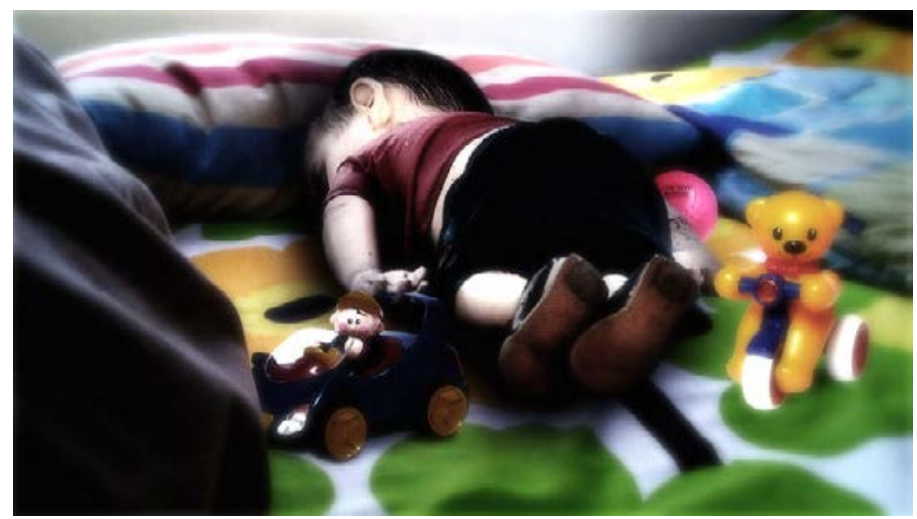

Il. 4. Przeramowanie: grafika autorstwa Birdana Sahy

\section{Taktyka 2: Rozdwojenie ramy}

Na jednym z przedstawień - autorstwa Kayleda Karajaha - twórca umieścił wewnętrzną ramę, dzielącą obraz na dwie asymetryczne przestrzenie: „jak powinno być” (3/4 obrazu z lewej strony) i ,jak jest” (1/4 z prawej), lub ,jak było” i ,jak jest”. Znak-ciało chłopca przecina symetrycznie ów wertykalny podział, objawiając rozdwojone znaczenie (lewa połowa oznacza sen, prawa śmierć), a zarazem moc postulatywno-krytyczną, co pozwala na osadzenie przekazu w rejestrze utopii (jak powinno być / jak jest) lub nostalgii (jak było / jak jest), w których pierwszy z wymienionych członów waloryzowany jest pozytywnie jako nieobecny stan pożądany.

$\mathrm{W}$ innym przypadku dwie ambiwalentne ramy (rama drzwi do sypialni oraz rama ilustracji na okładce gazety) oraz odpowiadające im dwa tożsame znaki o przeciwnych znaczeniach umieszczone zostały wewnątrz jednego obrazu.

mąk utonięcia, zamiast tego strumienie wody przedstawione są jako: czułe objęcia (www.boredpanda.com/sleep-deep-in-my-shoulders-here-is-your-safe-home/, http://www.boredpanda.com/the-warmest-embrace/ [data dostępu: 14.02.14]), kołdra (www.boredpanda.com/just-sleeping/ [data dostępu: 14.02.14]) czy dłoń unosząca troskliwie ciało chłopca (www.boredpanda.com/sleep-my-child/ [data dostępu: 14.02.14]). 
NIEZNOŚNA LEKKOŚĆ POCIESZENIA, NIEZNOŚNA MIAŁKOŚĆ PROTESTU...

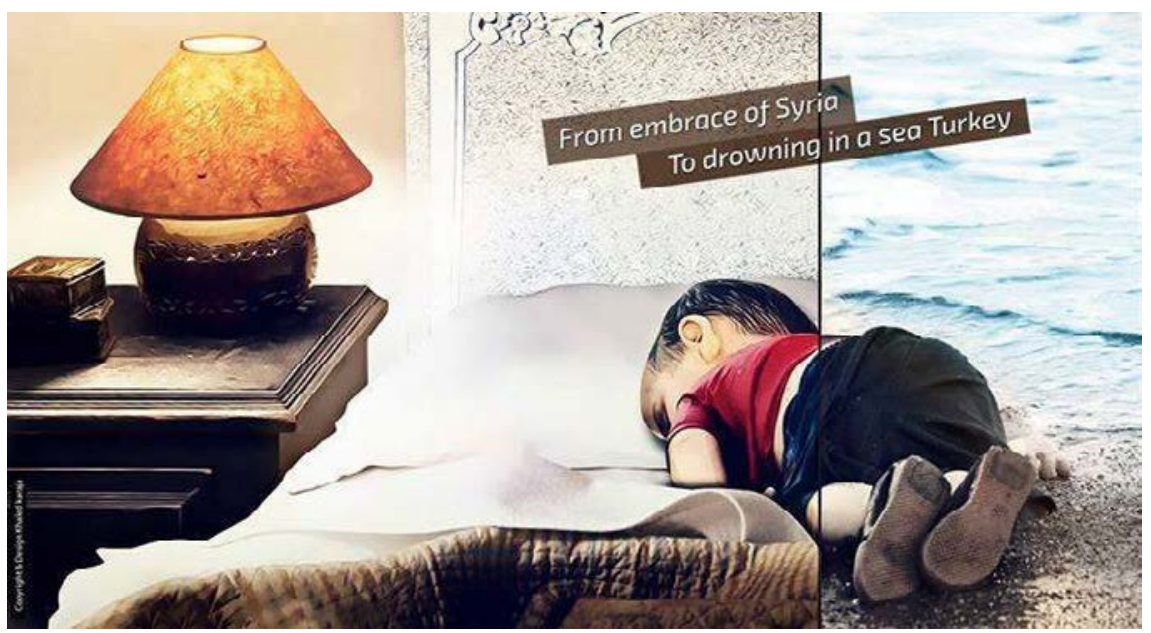

Il. 5. Rozdwojenie ramy: grafiki autorstwa Kayleda Karajaha

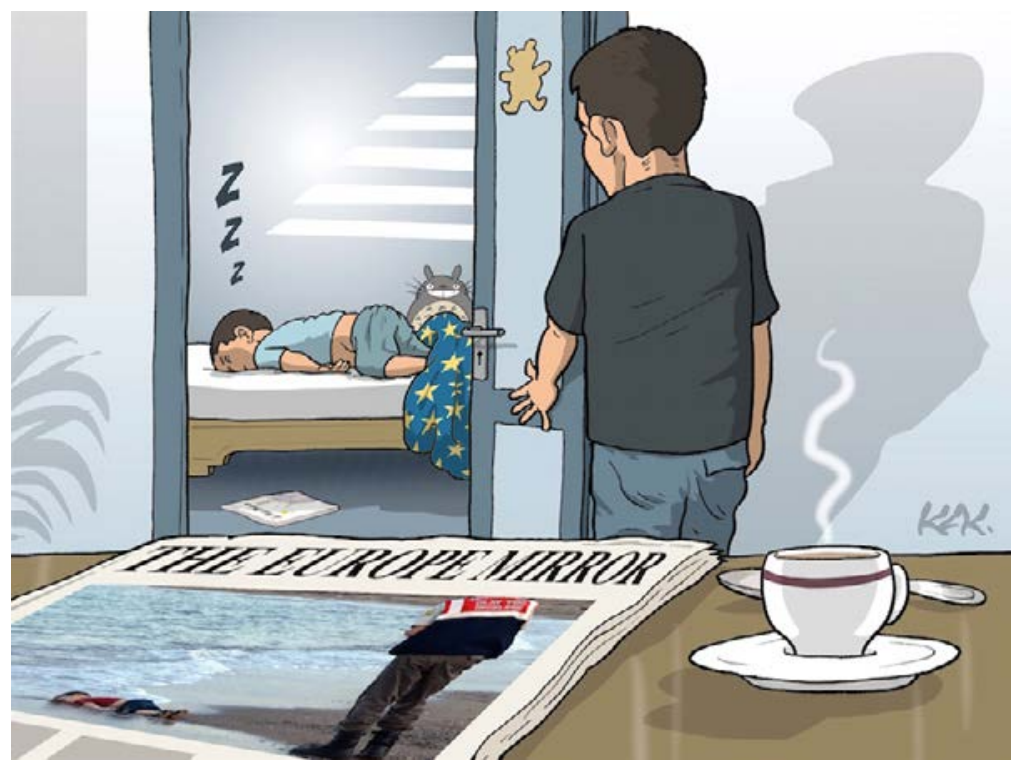

Il. 6. Rozdwojenie ramy: grafika autorstwa francuskiego rysownika o pseudonimie Kak 


\section{Taktyka 3: Przeznakowanie}

Inna taktyka wyzyskuje $\mathrm{z}$ kolei asocjacje związane $\mathrm{z}$ kontekstem przestrzennym - plaża jest wszak miejscem odpoczynku, beztroski i zabawy. Zachowując więc oryginalne ramy, twórcy przeistaczają sam znak (w odróżnieniu od wcześniej przedstawionej praktyki, tę można nazwać „przeznakowaniem"), który pozostaje rozpoznawalny poprzez swe dystynktywne cechy (kolor stroju, ciemne, krótko przystrzyżone włosy). Działanie postulatywno-krytyczne jest tu analogiczne jak w przypadku przeramowania: utopijne bądź nostalgiczne „tak powinno być” wypełnia płaszczyznę obrazu, podczas gdy bolesne „tak jest” tkwi w powidoku zdjęcia pierwotnego, ale nie tylko - po uważniejszym wpatrzeniu się w grafikę autorstwa Gunduza Akhayeva dostrzeżemy, że tym, co lepi z piasku chłopiec na plaży (a właściwie ulepił, gdyż aktualnie skupiony jest na wykańczaniu domku z piasku, który jakby chciał unieść i zabrać ze sobą), jest ciało, którego układ znamy z fotografii Nilüfer Demir. Ten pośmiertny odlew (rękoma samego zmarłego uczyniony, a przecież zmarli nie tworzą własnych przedstawień, co najwyżej, jako zmarli in spe, kopią swój grób - tu ziemi ubywa, a nie przybywa - ta okrutna reminiscencja również prześwieca przez ten obraz ${ }^{22}$ ) narusza gładką jednolitość przedstawienia - wtapiając się w nie na poziomie estetycznym, radykalnie się odeń oddziela na płaszczyźnie etycznej. Inną drogą poszedł artysta o pseudonimie ugurgallen. Na jego grafice - również utrzymanej w sielankowo-nadmorskiej konwencji - znak-ciało chłopca pozostał nienaruszony, ale jego nieobecne odniesienie (utopijne bądź nostalgiczne) objawia się pod postacią indeksu-cienia, cienia rzucanego przez to ciało-znak, ale niebędącego jego cieniem (gdyż nieodpowiadającego mu zarówno fizykalnie, jak i semantycznie). Widzimy jedynie bawiący się wiaderkiem cień-indeks tego, czego nie ma, a co było lub powinno być; miejsce usuniętego z przedstawienia - tak jak usuniętego $\mathrm{z}$ istnienia - chłopca bawiącego się na plaży zajmuje gładka, seledynowa tafla pustego morza i niegroźnie zachmurzone niebo.

22 Ale czy na tej ilustracji jest Aylan Kurdi, czy jego postać nieobecna i widmowa, postać $\mathrm{z}$ „tak było” lub „tak powinno być”, utopia lub nostalgia obwieszczająca swą nieziszczalność poprzez budowanie „zamków z piasku”? 


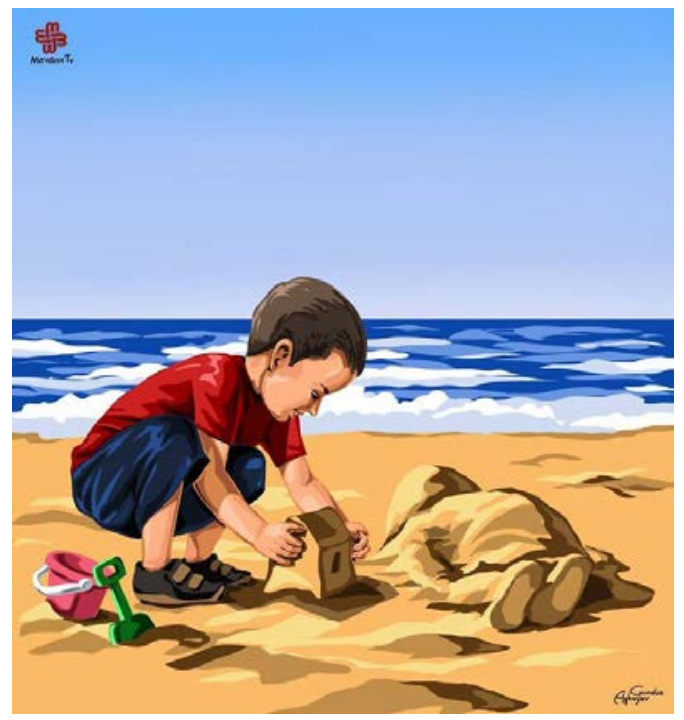

Il. 7. Przeznakowanie: grafika autorstwa Gunduza Aghayeva

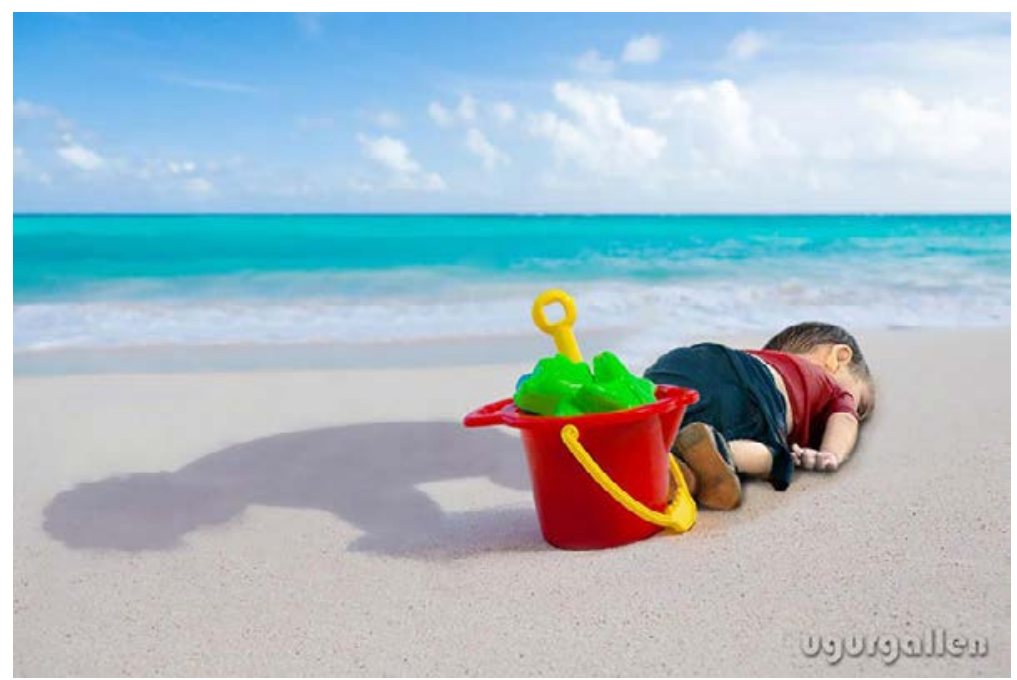

Il. 8. Znak i jego cień: grafika autorstwa artysty o pseudonimie/nicku ugurgallen 
Taktyka 4: Żywy obraz

Inny jeszcze rodzaj wizualnego protestu, a zarazem hołdu i aktu solidarności, ma charakter performansu. Je suis Aylan ${ }^{23}$ - zdaje się mówić chiński artysta Ai Weiwei, który dał się sfotografować na nieodległej od Bordum greckiej plaży w Lesbos w pozycji „na Aylana” (plaża jest plażą kamienistą, nie piaskową, zdjęcie jest czarno-białe, osoba na nim nie jest chłopcem, lecz mężczyzną w średnim wieku o wyraźnych rysach azjatyckich, a jednak nawiązanie pozostaje czytelne). Nous sommes Aylans - mówi trzydziestu Marokańczyków, którzy ubrani w czerwone t-shirty i dżinsowe spodnie zalegli na kilkanaście minut $\mathrm{w}$ bezruchu $\mathrm{z}$ brzuchami do ziemi i twarzami zwróconymi w lewo na plaży w Rabacie ${ }^{24}$. „Nie, nie jesteście” - brzmi odpowiedź realnego i faktycznego - „za chwilę wstaniecie i udacie się do swoich domów, a ten chłopiec, którego udajecie, nie żyje i nigdy nie wstanie". Już sama nazwa tej praktyki obnaża uzurpatorstwo jej uczestników: żywy obraz (tableau vivant). „Nie jesteście Aylanem Kurdi” - „Ale moglibyśmy być” - odpowiadają oni - „tak jak i ty”. Nie jest to z pewnością rodzaj psychodramy - albo jej internetowego wydania typu ice bucket challenge - wprowadzającej uczestników i widzów w kontemplację memento mori. Jeśli już, to apelującej do nas, byśmy wznieśli się na płaszczyznę empatii, współodczuwania - ale $\mathrm{z}$ kim? $\mathrm{Z}$ topielcem? $\mathrm{Z}$ trupem? $Z$ Aylanem Kurdim, który już niczego nie może odczuwać, gdyż nie żyje i jego ciało spoczywa w ziemi w syryjskiej wiosce Kobane, a i wówczas, na plaży w Bodrum, niczego już nie czuł?

Okazuje się zatem, że nie tylko osoby uczestniczące w tych praktykach i przedstawione na ich obrazach nie sq Aylanem Kurdi, ale też ten, kogo naśladują, w kogo się wcielają, nie jest Aylanem Kurdi. Aylan Kurdi usunięty zostaje nie tylko $\mathrm{z}$ tych przedstawień, ale i z fotografii pierwotnej której powidoki nadają im moc krytyczną - i przechodzi w rejestr mitu

${ }^{23}$ Wykorzystuję tu globalne hasło protestu-solidarności używane w mediach społecznościowych, i nie tylko, po ataku terrorystów islamskich na redakcję francuskiego pisma satyrycznego „Charlie Hebdo” - „Je suis Charlie”.

${ }^{24} \mathrm{http}$ //www.dailymail.co.uk/news/article-3227703/Thirty-people-recreatedeath-Alyan-Kurdi-laying-sand-Moroccan-beach-dressed-clothes-drownedSyrian-boy.html [data dostępu: 19.02.16]. 
(rozumianego tu tak, jak przedstawił go Roland Barthes). Mit, w ujęciu Barthes’a, jest „słowem skradzionym i oddanym. Tyle że słowo zwrócone nie jest już tym samym słowem, które skradziono: kiedy je zwracano, nie umieszczono go dokładnie na swoim miejscu" ${ }^{25}$. Mit traktuje znak jako pustą formę, w którą może wtłoczyć sens. Aylan Kurdi nie przestaje być sobą, ale jest już nie przede wszystkim sobq, jest bardziej Uchodźcą albo Ofiarą Wojny, albo Drugim Człowiekiem - lub też, czemu by nie - Uchodźcami, Ofiarami Wojny, Ludzkością.

Ai Weiwei i trzydziestu Marokańczyków jednak nie tyle kradną znak, co kradną mit, a właściwie - dopiero w akcie owej kradzieży dowiadują się, że tym, co kradną, nie jest znak, lecz mit. Tak zawrotnego mechanizmu mimetycznej mityzacji Barthes w swoim schemacie „wtórnego systemu semiologicznego" nie przewidział ${ }^{26}$.

25 R. Barthes, Mit dzisiaj, [w:] idem, Mitologie, tłum. A. Dziadek, Warszawa 2000, s. 257.

${ }^{26}$ Cyniczny dyskurs mówi, że poprzez ten akt osoby te mityzują przede wszystkim i mimochodem same siebie - jako Zaangażowanego Artystę i Wrażliwe, Współczujące Jednostki. Nie zamierzam się dołączać do tych głosów. Jeśli jednak w kreowaniu zbiorowych wyobrażeń skazani jesteśmy na mit, to całym sobą stoję po stronie tego właśnie mitu, wbrew mitowi przeciwstawnemu, który dominuje w publicznym dyskursie. Intencje artysty oraz protestujących/składających hołd są z pewnością czytelne: pragną oni zwiększyć „siłę rażenia” pierwotnej fotografii poprzez albo autorytet Tłumu i moc Liczby (trzydzieści osób to co prawda niewiele, ale zawsze więcej niż jedna; trzysta z pewnością robiłoby „większe wrażenie”), albo autorytet i moc Sztuki, a zarazem „przedłużyć” ją w tym powtórzeniu. Siódmego września 2015 roku, a więc pięć dni po śmierci Aylana Kurdiego, palestyński artysta Osama Esbaitah wykonał na plaży w indyjskim Puri około pięciometrową rzeźbę z piasku odzwierciedlającą pozycję i strój (ubrania oraz włosy zostały pokolorowane) chłopca (zob. http://m.chinadaily.com.cn/en/2015-09/08/content_21817372. htm [data dostępu: 10.11.16]). Piętnastego lutego 2016 roku wspomniany Ai Weiwei zebrał czternaście tysięcy kamizelek ratunkowych i owinął nimi kolumny berlińskiego Shnauspielhous. Miesiąc później islandzki UNICEF zorganizował akcję polegającą na przyniesieniu czterystu maskotek - każda symbolizować miała jedno dziecko, które utonęło od czasu śmierci Aylana Kurdiego podczas próby ucieczki z Syrii drogą morską - i rozmieszczeniu ich na kamienistym brzegu wyspy (zob. http://grapevine.is/news/2016/03/15/lets-say-stop/ [data dostępu: 10.11.16]). 


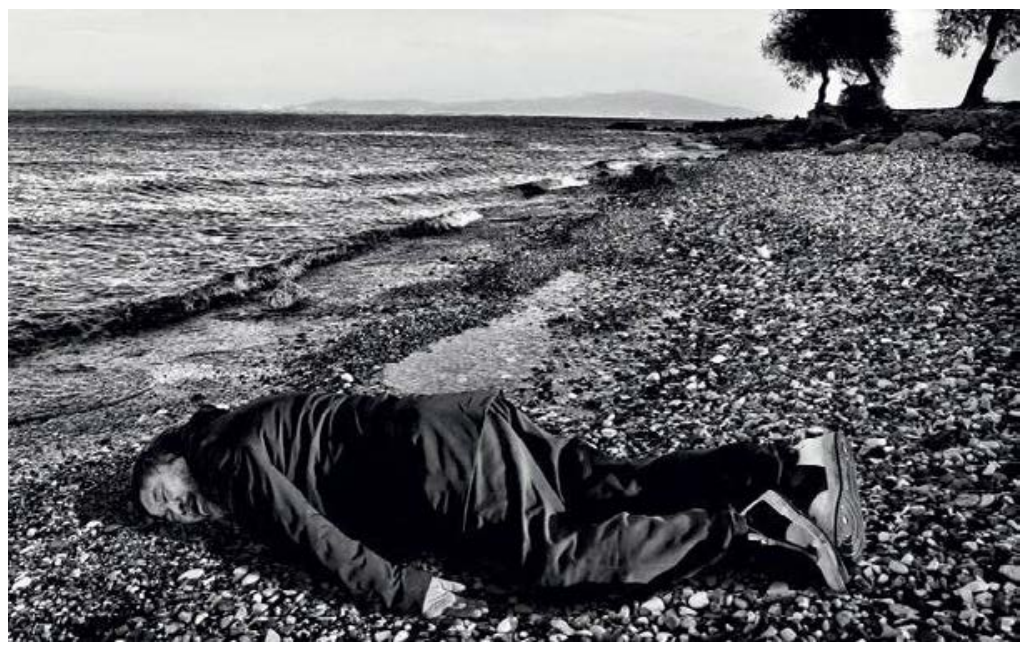

Il. 9. Żywy obraz: Ai Weiwei (fot. Rohit Chawla)

Taktyka 5: „Butelki benzyny i kamienie”

Wykorzystuję tutaj te stereotypowe rekwizyty, a zarazem narzędzia broni, które tłum, lud, wymierza przeciw bezduszności, niesprawiedliwości, okrucieństwu czy ślepej obojętności władzy, by przedstawić ostatnią z wyróżnionych wizualnych taktyk protestu. O ile w większości z przedstawionych wcześniej obrazów aspekt mityczny był mniej lub bardziej utajony, tutaj zaczyna on dominować, a obraz sytuuje się w pełni w rejestrze winy i publicznego żalu. Ciało-mit zostaje wystawione na pokaz, rzucone pod nogi władzy, wymierzone przeciw niej, jakby z okrzykiem: „Patrzcie, co zrobiliście!”, „Macie krew na rękach!”. Wyolbrzymione do granic monstrualności, stanowić ma ewidentny dowód winy służący wytrąceniu możnych tego świata $\mathrm{z}$ ich indyferencji i polityki „umywania rąk”.

W tym wypadku każdorazowo pojawia się jednak pytanie, czy przekaz został właściwie zaadresowany. Różne grafiki kierują swoje J’accuse w odmienne strony, zrzucając winę to na ONZ (i konszachty Zachodu ze światem arabskim: tajemne układy, broń za ropę, petrodolary itp.), to na świat arabski (toczący swoje nieustanne wojny) ${ }^{27}$, to na Unię Europejską (z jej polityką

27 www.boredpanda.com/the-leaders-watching/, www.boredpanda.com/arab/ [data dostępu: 19.02.16]. 
graniczną, działalnością Frontexu itp. $)^{28}$. Już sama ta wielość potencjalnych winowajców rozmywa głos wyrzutu i sprzeciwu dobiegający z bezwładnego i niemego ciała chłopca i wikła je w szereg retorycznych fechtunków służących praktycznie wyłącznie cedowaniu odpowiedzialności na innych. Z „butelki benzyny i kamienia” ciało chłopca staje się „zgniłym jajem” czy "gorącym ziemniakiem” z dziecięcej zabawy, przerzucanym czym prędzej $\mathrm{z}$ rąk do rąk, które wszystkie pozostają niesplamione.

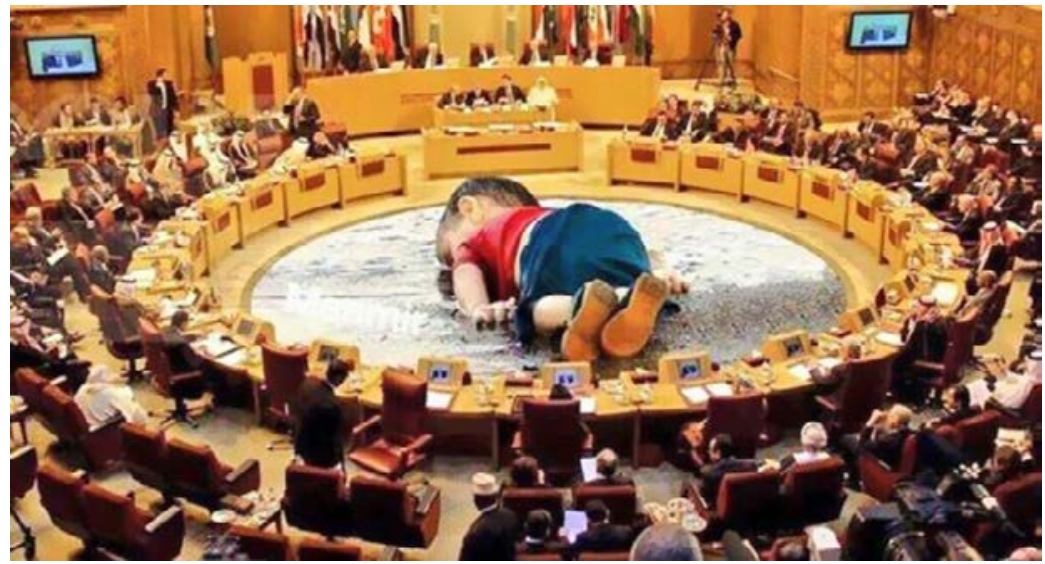

Il. 10. „Patrzcie, co zrobiliście” - grafika autorstwa anonimowego internauty ${ }^{29}$

\section{NIEZNOŚNA LEKKOŚĆ POCIESZENIA}

\section{ZAWÓD: REPORTER. SPECJALNOŚĆ: FOTOGRAFIA DZIECIĘCA}

Przeoczyłem oczywisty, a znamienny fakt: fotografie Nilüfer Demir przedstawiają nie tyle trupa, co trupa dziecka. W poruszonej przez Sontag kwestii wpływu ukazywania okrucieństw zadawanych ludności cywilnej na wypracowanie nowego standardu reakcji na cierpienie, figurze dziecka należałoby przypisać miejsce szczególne. Dziecko, wyposażone w swą niewinność, delikatność, bezbronność, podatność na zranienie, ma zdolność

${ }^{28}$ www.boredpanda.com/stap-looking-away/ [data dostępu: 19.02.16].

29 Analogiczna grafika: www.boredpanda.com/in-memory-of-aylan-kurdi-by-achraf-baznani/ [data dostępu: 19.02.16] 
zarówno do kumulowania w sobie całego bezsensownego tragizmu wojny, jak i wyostrzania problemów etycznych związanych z przedstawianiem „widoku cudzego cierpienia”.

Opowieść o kulisach wykonania fotografii przez Nilüfer Demir łączy w sobie elementy mitologii „decydującego momentu” i misji fotoreportera (na przeszkodzie której stają ludzko-kobieco-matczyne odruchy): „Poczułam się nieomal sparaliżowana, gdy zobaczyłam ciało dziecka [...]. W tym samym momencie, jako fotograf, mam swoje zadanie, które nie pozwala marnować czasu na gapienie się, na bezruch. Dlatego zrobiłam zdjęcie”30. Spytana o swoje odczucia i refleksje związane z popularnością fotografii, którą wykonała, fotoreporterka odpowiada: „Z jednej strony, chciałabym nie być zmuszona do wykonania tego zdjęcia, o wiele bardziej wolałabym wykonać fotografię Aylana bawiącego się na plaży [sic!] niż jego ciała. To, co ujrzałam, wywarło na mnie okropne wrażenie, które budzi mnie po nocach. Jednakże jestem zadowolona, że świat [w tekście „word”, zapewne literówka - przyp. P.J.] w końcu troszczy się i opłakuje martwe dzieci. Mam nadzieję, że moje zdjęcie może wnieść wkład w zmianę tego, jak patrzymy na emigrację w Europie, i sprawi, że nikt więcej nie będzie musiał ginąć" ${ }^{31}$.

Jak zawsze w tego typu okolicznościach, pojawiły się też głosy sprzeciwu i krytyki ${ }^{32}$. Zacytuję jeden z nich, autorstwa Brendana O’Neilla, felietonisty brytyjskiego magazynu „The Spectator”, gdyż odnosi się on do nowej

30 I. Küpeli, wywiad z Nilüfer Demir; www.vice.com/read/nilfer-demir-interview-876 [data dostępu: 19.02.16).

31 Ibidem.

32 Wśród przeróbek fotografii Demir można znaleźć i takie, które wymierzone są w media. Na jednej z nich, autorstwa Michela Kichky, dookoła ogromnego ciała Aylana ustawionych jest siedem małych postaci z kamerami, aparatami i statywami (https://fr.kichka.com/2015/09/03/aylan-kurdi/ [data dostępu: 21.02.16]), inna przedstawia dwójkę kamerzystów z obiektywami wycelowanymi w Aylana, u góry zaś znajduje się znany z gry w jednorękiego bandytę napis „Jackpot” oznaczający zgarnięcie pełnej puli (podpis pochodzi od Guy’a Deborda: „Społeczeństwo spektaklu"; www.boredpanda.com/society-of-the-spectacle-by-lhomme-jaune/ [data dostępu: 21.02.16]). Na jeszcze innej fotoreporter (mężczyzna) przykucnął na stosie dziecięcych ciał leżących w kałuży krwi (podpis: „Ofiary terroryzmu”), tylko po to, by wykonać zdjęcie jednego Aylana (podpis: „Ofiara migracji”; www.boredpanda. com/cynizm/ [data dostępu: 21.02.16]). 
formy jałowego współczucia u odbiorcy, charakterystycznej dla epoki Web 2.0, czyli tak zwanego „slacktywizmu”" ${ }^{33}$ " „Czyż nie jest to najsmutniejsze zdjęcie, jakie kiedykolwiek zobaczyłeś? I ohydne? Szybko, udostępnij je! Pokaż swoim przyjaciołom - na Twitterze, Facebooku - żeby też poczuli się zasmuceni i zohydzeni. Zbierzcie się wszyscy i pogapcie na martwe syryjskie dziecko"34. Sam autor określa to mianem "moralnej pornografii” i uznaje za przejaw obłudnego narcyzmu, służącego niczemu więcej jak samozadowoleniu i moralnemu oczyszczeniu odbiorcy: „Ja też się smucę, ergo: jestem dobry”. Pojawiły się także, jak przy okazji wielu ,ikonicznych” fotografii, podejrzenia, że cała scena została zaaranżowana - podejrzenia poparte zresztą, fotograficznymi, a jakże $\mathrm{e}^{35}$, dowodami (współczujący i zagniewani odbiorcy, oczekujący „autentyczności”, padliby więc ofiarą manipulacji?) - a ciało chłopca przeniesione przez tureckiego strażnika nadbrzeżnego z miejsca, gdzie wyrzuciło je morze, w bardziej „malowniczą” przestrzeń i ułożone $w$ tej pozie, $w$ jakiej zostanie zapamiętane.

Niezależnie od tych kontrowersji i spekulacji, zdjęcie Nilüfer Demir przejdzie do kanonu „widoków cudzego cierpienia” w dziale „dzieci”, wraz z równie słynnymi fotografiami Nicka Uta (1972, wietnamska dziewczynka poparzona napalmem - omal-nie-trup) czy Kevina Cartera (1993, sudańska dziewczynka umierająca z głodu - już-zaraz-trup). W kulturze konwergencji ta łączność nie mogła zostać niezauważona i niewyzyskana przez twórców internetowych „powtórzeń z różnicą".

Na jednej z ilustracji sprowadzone do zarysów zdjęcie Uta umieszczone jest, niczym bilbord (anty)reklamowy, w morzu, podczas gdy na brzegu spoczywa znana sylwetka Aylana Kurdiego, który niejako wpatruje się w obraz (by osiągnąć ten efekt, trzeba było przekręcić ciało o 90 stopni i zorientować

${ }_{33}$ Określenie Malcolma Gladwella, publicysty „New Yorkera”, neologizm łączący słowa 'aktywizm' i 'slack', czyli 'bezczynność, 'leniuchowanie', który odnosi się do wszelkich form łatwego i - koniec końców - jałowego zaangażowania, ograniczającego się do „lajkowania”, share'owania (w języku polskim brzmi to prawie jak 'żerowanie'), deklarowania udziału, podpisywania petycji itp.

${ }^{34}$ B. O'Neill, http://blogs.spectator.co.uk/2015/09/sharing-a-photo-of-the-dead-syrian-child-isnt-compassionate-its-narcissistic/ [data dostępu: 10.02.16].

${ }_{35} \mathrm{https} / /$ anongalactic.com/syrian-boys-body-was-moved-before-photos-were-taken/ [data dostępu: 19.02.16]. 
równolegle do linii brzegu). Wietnamska dziewczynka (Kim Phúc, wciąż żyje i prowadzi fundację zajmującą się pomocą dla dziecięcych ofiar wojny), stawiając krok prawą nogą - tylko ten element jej ciała, przeszywający dolny brzeg ramy baneru, przedstawiony jest w kolorze - opuszcza obraz i wchodzi jednocześnie do morza (twórca zaznaczał to kilkoma kreskami sygnalizującymi rozprysk wody), jak i do teraźniejszości Aylana. Wyjście z obrazu jest więc jednocześnie podróżą w czasie. Choć bilbord umieszczony w wodzie jest cokolwiek kuriozalny (tym bardziej że służy on chyba uprawdopodobnieniu tego symbolicznego wyobrażenia), jego skryty wydźwięk jednoczy Kim Phúc i Aylana Kurdiego w rejestrze mitycznym - jako Dzieci-Ofiary Wojny. Na innej grafice zmultiplikowane i rozmazane sylwetki Kim Phúc, połączone dłońmi, tworzą coś w rodzaju szpaleru, wewnątrz którego spoczywa ciało Aylana Kurdiego (można domniemywać, że jest to krąg, choć bardziej niż dziecięcą zabawę „w kółko” przypomina średniowieczne wyobrażenia dance macabre). Powielone sylwetki spoglądają wyzywająco w stronę widza (łamiąc zasady tak szpaleru, jak kręgu, które zorientowane są ku wewnątrz).

Imienia sudańskiej dziewczynki nie znamy i nie poznamy, a jej dalszych losów możemy się wyłącznie domyślać, bazując na nieprawdopodobieństwie nadziei, pozostała jedynie jako obraz, zastygła w „decydującym momencie”, gdy za jej plecami przycupnął sęp (krytycy mówią, że Carter mimochodem uwiecznił na zdjęciu samego siebie). Nie wiem, czy powidok nagrodzonej Pultizerem fotografii na grafice przedstawiającej Aylana, a w jego tle właśnie sępa z głowicami broni sterczącymi niczym niesforne pióra (i kolejnym adresatem winy wypisanym na piersi - „światowy przemysł militarny”), był w tym wypadku zamierzonym zabiegiem autorskim. Bardziej jednoznaczne odwołanie występuje na innym rysunku składającym się z trzech części. Autor $\mathrm{u}$ góry przedstawił rysunkowe wersje znanych fotografii Cartera i Demir, wraz z lokalizacją geograficzną i czasową, na dole zaś wyimaginowane spotkanie sudańskiej bezimiennej dziewczynki (która na tę okazję zmieniła się w chłopca, ściągnęła naszyjnik, ale założyła przypominające pieluchę majtki) z Aylanem Kurdim (któremu z kolei zdążyły wypłowieć włosy). Spotkanie odbywa się gdzieś w chmurach, pod czujnym okiem smutnego słoneczka: „Wciąż tak samo?” - pyta sudański chłopiec, „Wciąż tak samo" - odpowiada Aylan. Świat nadal patrzy, jak umierają niewinne dzieci, i pozwala na to. 


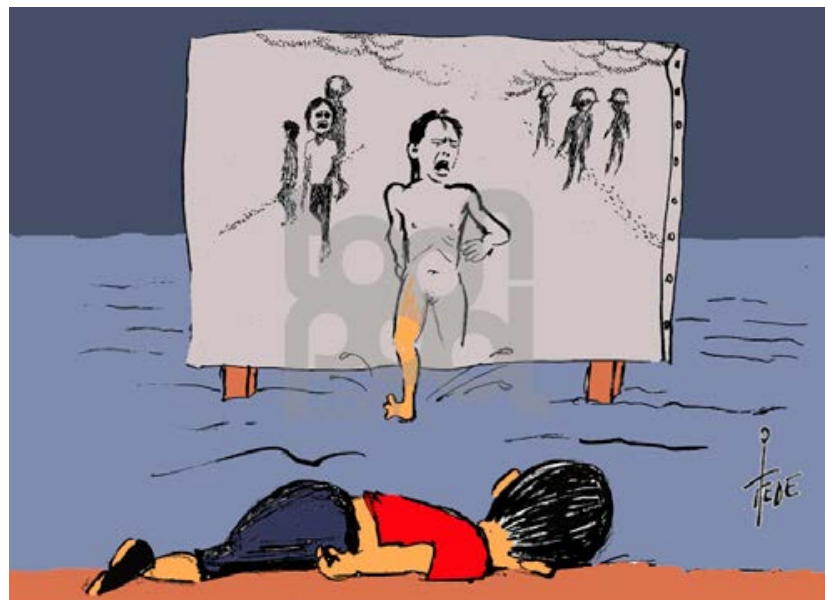

Il. 11. Pamięć obrazu: grafika autorstwa Joachima Tiedemanna

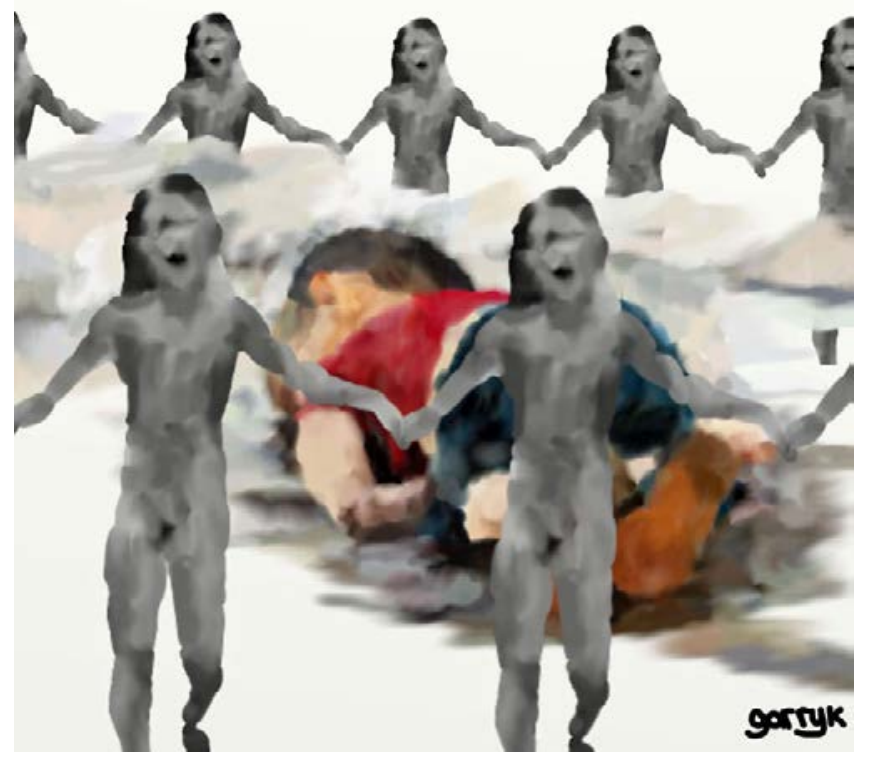

Il. 12. Pamięć obrazu: grafika autorstwa Garry'ego J. Kendellena 


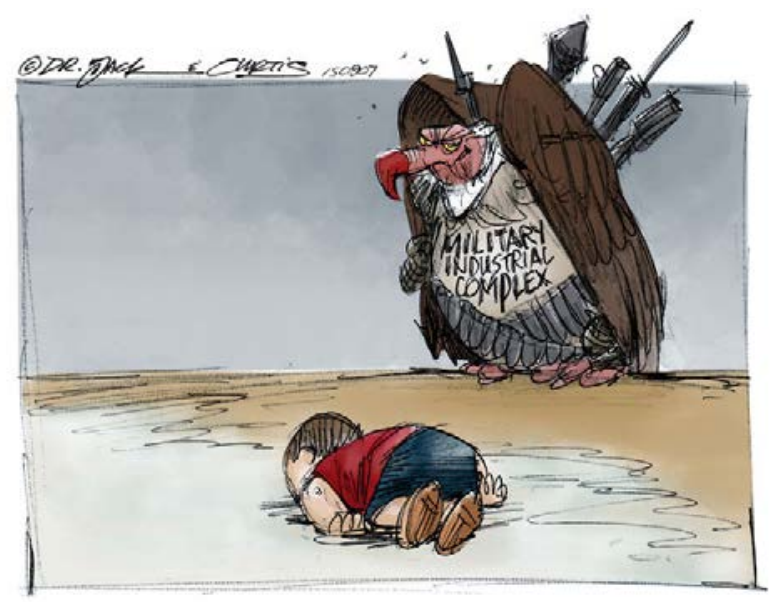

Il. 13. Pamięć obrazu: grafika autorstwa duetu Dr Jack \& Curtis
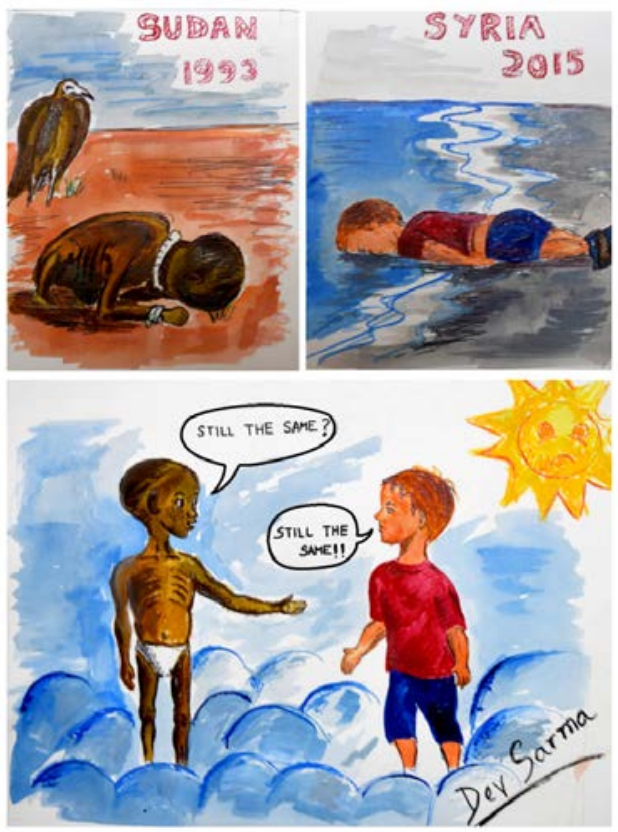

Il. 14. Pamięć obrazu: grafika autorstwa Hrishikesha Dev Sarmy 


\section{O, AYLANIE! O, LUDZKOŚCI!}

Stawką w grze, w której uczestniczy wiele internetowych obrazów, jest wiara w ludzkość. Przykładowo, wyszukiwarka na portalu YouTube odnajduje około 25000 wyników dla zapytania „losing faith in humanity” i 79000 dla „restore your faith in humanity" (z czego można wnosić, że albo nie jest aż tak bardzo źle - akty Dobra przeważają nad działaniami Zła - albo wręcz przeciwnie, wiara w ludzkość jest tak nadwątlona, że potrzebuje trzykrotnie większej armii obrazowej). Ludzkość jako taka na internetowych przeróbkach fotografii Demir obecna jest najczęściej pod postacią dłoni (w liczbie pojedynczej lub mnogiej), które służą tu jako pars pro toto człowieka (przy czym są to raczej dłonie kobiece, matczyne, stereotypowo konotujące czułość, delikatność, opiekuńczość, w przeciwieństwie do rąk męskich, konotujących raczej solidność, pewność, siłę), który to, zredukowany do dłoni, człowiek-kobieta jest z kolei pars pro toto ludzkości (język polski pozwala tu na znaczącą grę słów: synekdocha). Cóż jednak poza pustym gestem - jednocześnie symbolicznym, utopijnym i spóźnionym, na wieki zaprzepaszczonym - wyrażają te obrazy? Słyszę z ich strony jedno słowo: pociecha. Pytam: dla kogo?

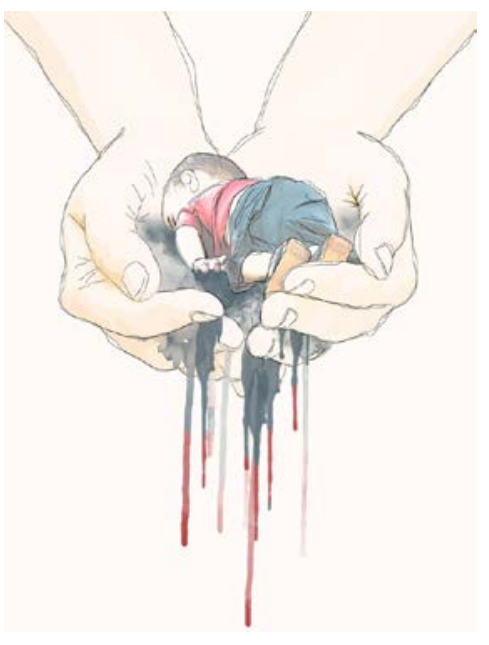

Il. 15. Synekdocha: grafika autorstwa Helen Savvy $y^{36}$

36 „To nie jest Anne Geddes” - głosi podpis na bardzo podobnym obrazku (www.boredpanda.com/ceci-nest-pas-anne-geddes/ [data dostępu: 19.02.2016]), którego autorka odwołuje się nie tylko do Magritte'a, ale i znanej fotografki małych dzieci. 
Znacznie mniej pozytywny obraz ludzkości pojawia się, gdy jest ona przedstawiona metonimicznie jako Świat (wizualnie: kula ziemska). Te przedstawienia są wyraźnie oskarżycielskie, a Świat - czyli wszyscy razem, czyli nikt konkretny - funkcjonuje jako (kolejny już) winowajca: „Thank you World” - głosi napis na baloniku, którzy trzyma w ręku leżący na plaży Aylan Kurdi na jednym z obrazków ${ }^{37}$ (inspirowane Banksym baloniki również często pojawiają się na przeróbkach fotografii Demir).

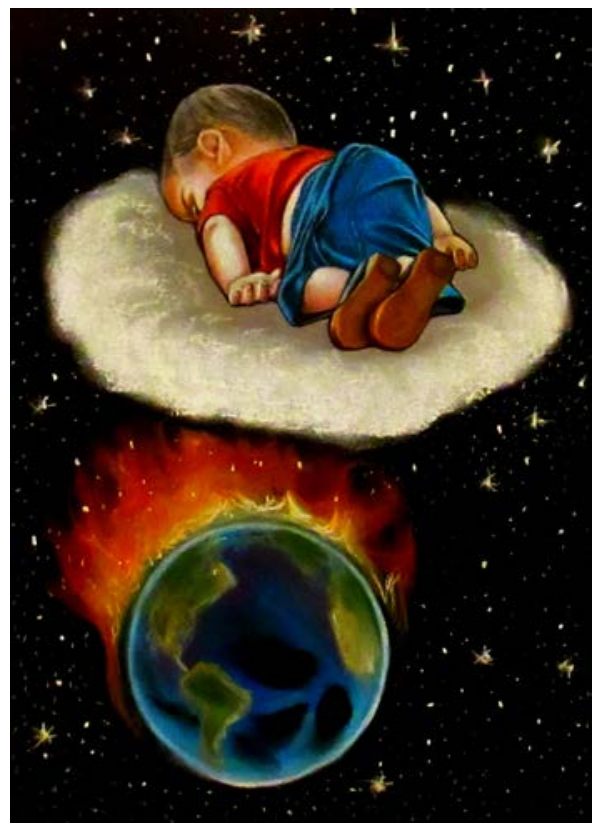

Il. 16. Metonimia: grafika autorstwa Dinko Arta

Na dwóch grafikach Aylan spoczywa na chmurze (śpi? nie żyje? - trudna sprawa) gdzieś ponad światem, który z kolei przedstawiony jest w kształcie kupy („opuszczam gówniany świat” - głosi podpis ${ }^{38}$ ) lub spowity ognistą łuną, która niejako ogrzewa legowisko chłopca (podpis: „lepsze miejsce”).

37 www.boredpanda.com/thank-you-world/ [data dostępu: 19.02.16].

38 www.boredpanda.com/leaving-a-shitty-world/ [data dostępu: 19.02.16]. 
Inna jeszcze przedstawia go, gdy leży - ponownie: na chmurze ${ }^{39}$ - przed zamkniętym ogrodzeniem przypominającym granice rezydencji bogaczy lub instytucji państwowych; koło chłopca znajduje się nieotwarty list (być może to wniosek o azyl, a za ogrodzeniem znajduje się ambasada lub urząd do spraw uchodźców), podczas gdy mężczyzna w niebieskim garniturze (urzędnik?) próbuje czym prędzej czmychnąć z tego miejsca i odciąć się od całej tej afery - głową mężczyzny jest kula ziemska, narysowana na niej, w kreskówkowej konwencji, twarz wyraża strach i przerażenie (czy tak właśnie wyglądają kierowcy uciekający z miejsca wypadku?), oczy działające jakby wbrew woli - zwrócone są ku temu, od czego mężczyzna próbuje uciec ${ }^{40}$.

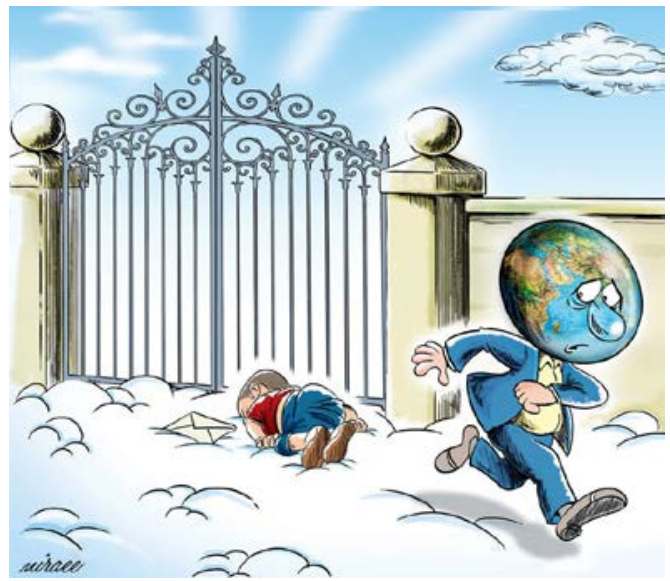

Il. 17. Metonimia: grafika autorstwa Aliego Miraee

\section{„POWIĘKSZYŁ GRONO ANIOŁKÓW”}

Zdecydowanie najliczniejsza grupa przedstawień wpisuje się w coś, co chciałbym określić jako „retoryka pocieszenia”. Retoryka ta obecna jest nawet

39 Co skądinąd nie przeszkadzało twórcy umieścić chmury też „na niebie”, a przynajmniej w miejscu na nie przeznaczonym zgodnie z powszechnie respektowaną konwencją przedstawiania.

${ }^{40}$ Jest jeszcze jedna grafika, na której chłopiec umieszczony jest, wyjątkowo, na rogalikowatym księżycu. Księżyc płacze. Podpis głosi: „Dirty world”; www.boredpanda.com/dirty-world/ [data dostępu: 19.02.16]. 
w przedstawieniach krytycznych - weźmy chociaż ostatnie przytoczone: dlaczegoż to twórca, mając wyraźnie oskarżycielskie intencje, nie wzbronił się przed ulokowaniem całej sceny na baśniowej chmurce?

Wiele „widoków cudzego cierpienia” ewokuje pytanie o „ciąg dalszy” (Kevin Carter nie umiał na nie odpowiedzieć; zrobił zdjęcie i poszedł dalej... robić zdjęcia). Dotyczy to, oczywiście, widoków omal-nie-trupów i już-zaraz-trupów. Pytania te, jak sądzę, wzbudza nie tyle „zwykła ludzka” troska czy podskórne pragnienie happy endu, ale potrzeba poznania, a następnie dostosowania swojej reakcji to tego, co poznane - w grę wchodzą żal lub ulga (poznania tego brak w historiach o tych, którzy wyszli z domu i nie wrócili; historiach o himalaistach, których ciał nie odnaleziono - niemożność przywdziana żałoby, niemożność przyjęcia pociechy; emocjonalne, egzystencjalne limbo).

Jednakże zarówno trup, jak i jego fotografia nie usuwają pytań o „ciąg dalszy”, tyle tylko, że odpowiedzi operować muszą w rejestrze fantastycznym (wyobraźniowym) lub religijnym (częstokroć wzajem się splatających). Kultura konwergencji nie jest pierwszą, która nadaje tym odpowiedziom obrazowe ciało. Jest natomiast chyba pierwszą, w której ten obraz jest tak irytująco naiwny. Chmurki już przerobiliśmy, dodajmy tylko, że są one wybitnie bezpiecznie, gdyż nie poruszają potencjalnie drażniących nut różnic religijnych czy kulturowych: chmurki są ogólnokulturowe i ponadreligijne. Znamy już też Aylana baraszkującego w piasku, dołóżmy kilka elementów aureolę i skrzydełka - by delikatnie zasugerować, że nie jest to „nasza, ziemska plaża”, a otrzymamy Aylana-Aniołka ${ }^{41}$ lepiącego zamki z piasku (u góry, w takich jakby chmurkach, stopniowo blaknie wspomnienie o pierwotnym obrazie). A oto i roześmiany święty Aylan ${ }^{42}$, ukończył właśnie piaskową

${ }^{41}$ Taktyka stylizowania zmarłych dzieci na aniołki była już obecna w epoce wiktoriańskiej, zob. A. Linkman, op. cit., s. 27.

${ }^{42}$ Ciało Aylana uległo pewnego rodzaju zbiorowej konsekracji, o czym świadczyć może reakcja na prowokacje (profanacje?) rysowników z „Charlie Hebdo”, po której większość internautów odrzekła: Je ne suis plus Charlie. Gwoli przypomnienia, pierwszy z rysunków przedstawia Aylana leżącego na plaży, obok zaś znajduje się baner reklamowy restauracji McDonald's z charakterystyczną postacią klauna Ronalda i ofertą promocji: „Dwa zestawy dziecięce w cenie jednego”, podpis na rysunku głosi: „Tak blisko do celu...” Na drugim, podpisanym „Dowód, iż Europa 
budowlę - koło niego cokolwiek jowialny jegomość w biblijnym wdzianku wieńczy dzieło, wtykając na szczyt białą flagę (podpis pod zdjęciem informuje, że to Jezus; Aylan był muzułmaninem, pewnie wolałby akurat $\mathrm{z}$ Mahometem się pobawić, ale who really cares $\left.{ }^{43}\right)$. Niezbyt skomplikowany w obsłudze program graficzny wystarczy, by Aylan drzemał sobie w najlepsze na gładkiej tafli wody wśród - a jakże - chmur (cokolwiek by one by tam robiły), albo po prostu w chmurach - jako aniołek lub nie - obok dwóch smutnych, przytulonych do siebie misiów siedzących na księżycu. Skoro już dorysowaliśmy Aylanowi skrzydełka i aureolę, otoczymy go ponadto świetlistą łuną, w rękę wsadźmy kwiat róży i dodajmy seledynowe, pastelowe tło. Równie łatwo wyczarować zwieszającego się z góry obrazu anioła (o dość przerażającej fizys, ale przecież nie to jest ważne), który wyciągnie miłosierne dłonie ku utrudzonej, niewinnej duszyczce Aylana. Wreszcie, by bicz niezgody siekł obojętną ludzkość do krwi, każmy Aylanowi patrzeć na swe osamotnione, dziecięce ciało spoczywające na brzegu morza, ale niech ten Aylan, który patrzy, będzie uśmiechnięty, niech znajduje się - to już się robi nudne, więc kończę, choć można tak długo - na chmurce, niech ma skrzydełka, a obok umieśćmy formularz z odmową prawa do życia i dopiszmy, na tle chmurki, półprzezroczystym Arialem: „Ile jeszcze utracimy w imię obojętności?” (dodajmy na koniec szczyptę prowokacji: tabliczkę „Zakaz śmiecenia”).

jest chrześcijańska”, widzimy kroczącego po wodzie Jezusa, podpis: „Chrześcijanie chodzą po wodzie", a obok zwrócone do góry nogi w krótkich czerwonych spodenkach (nawiązanie jest bardziej niż czytelne, zwłaszcza przy znajomości kontekstu), podpis: „Muzułmańskie dzieci toną”. Trzeci rysunek przedstawia Aylana z przyszłości i nawiązuje do sylwestrowych wydarzeń z Kolonii; podpis: „Kim stałby się mały Aylan, gdyby dorósł? Obmacywaczem tyłeczków w Niemczech".

${ }^{43}$ Znalazłem dwa rysunki, na których Aylan Kurdi przedstawiony jest jako Jezus: raz w żłóbku (www.boredpanda.com/without-faith-in-humanity/, podpis: „Kiedy wraz z obrazem dziecka umarła moja wiara w ludzkość” [data dostępu: 21.02.16]), raz zaś w formie piety (www.boredpanda.com/pieta/ [data dostępu: 21.02.16]). 


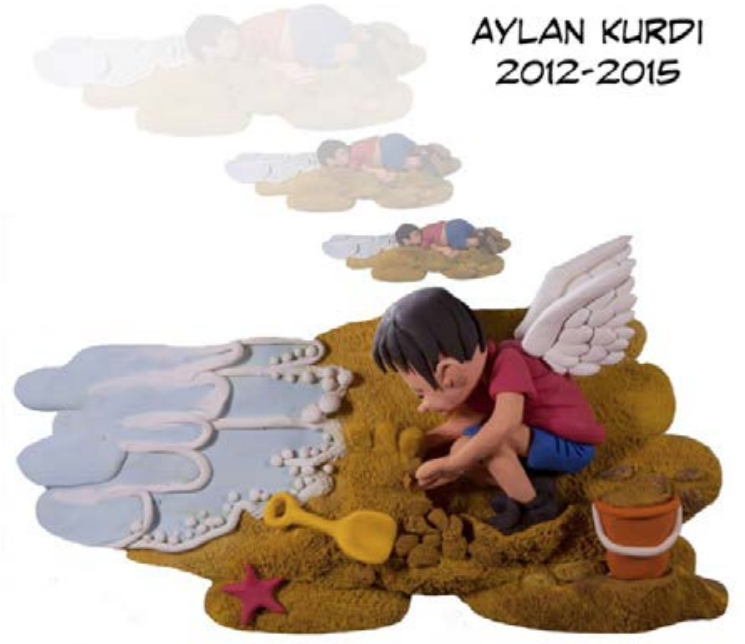

Il. 18. Retoryka pocieszenia: grafika autorstwa Edgara Humberto Alvareza

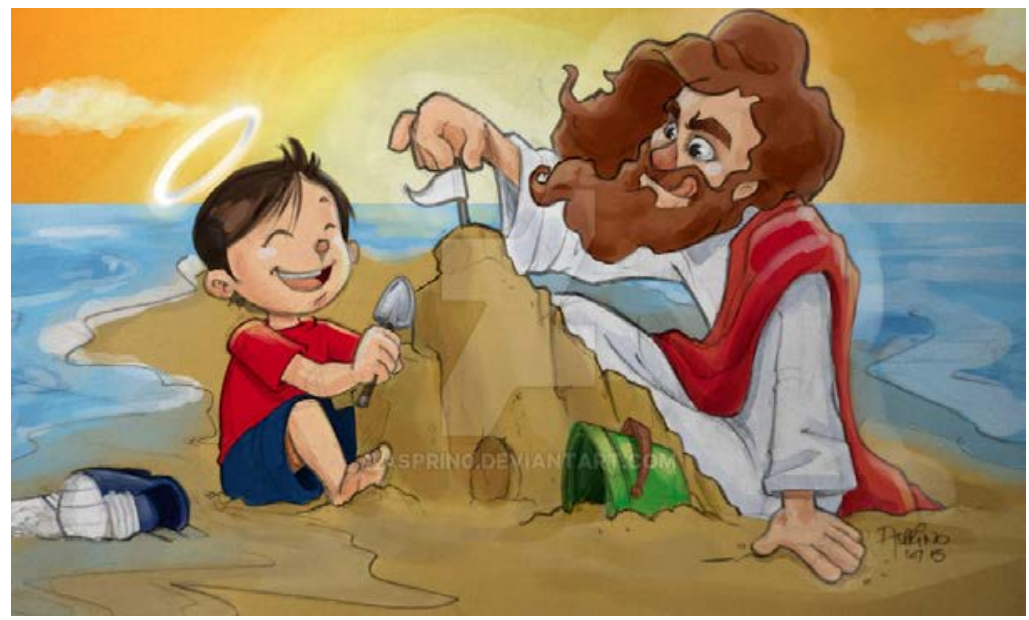

Il. 19. Retoryka pocieszenia: grafika autorstwa Asprino Leonardo 


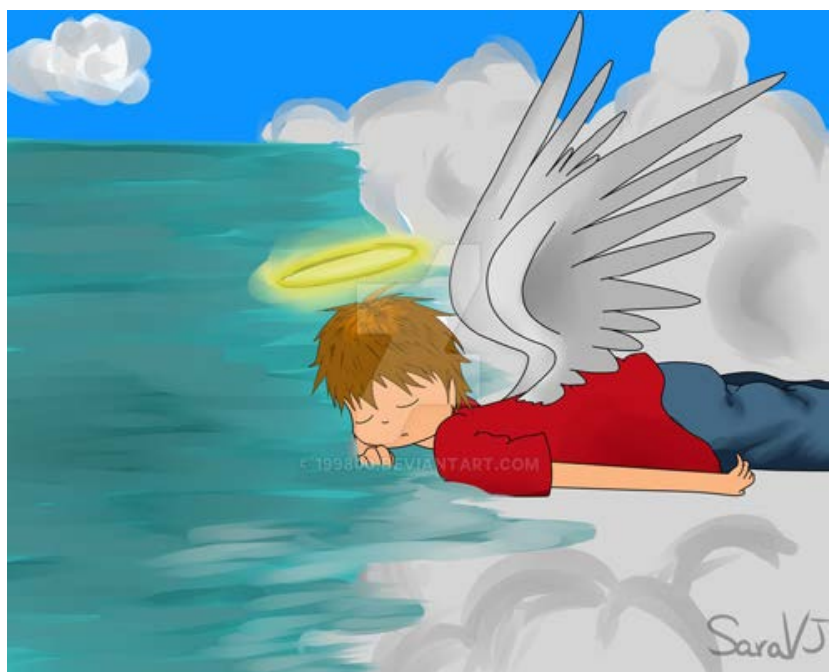

Il. 20. Retoryka pocieszenia: grafika autorstwa Sary VJ

\section{SEE humans BUT NO humanity}

Il. 21. Retoryka pocieszenia: grafika autorstwa Mariyany Kolevej 


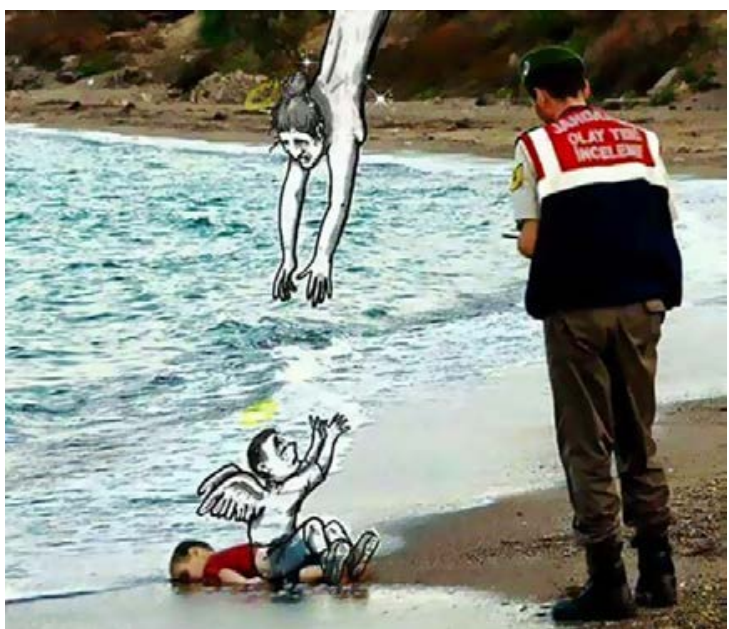

Il. 22. Retoryka pocieszenia: grafika autorstwa Dijwara Ibrahima

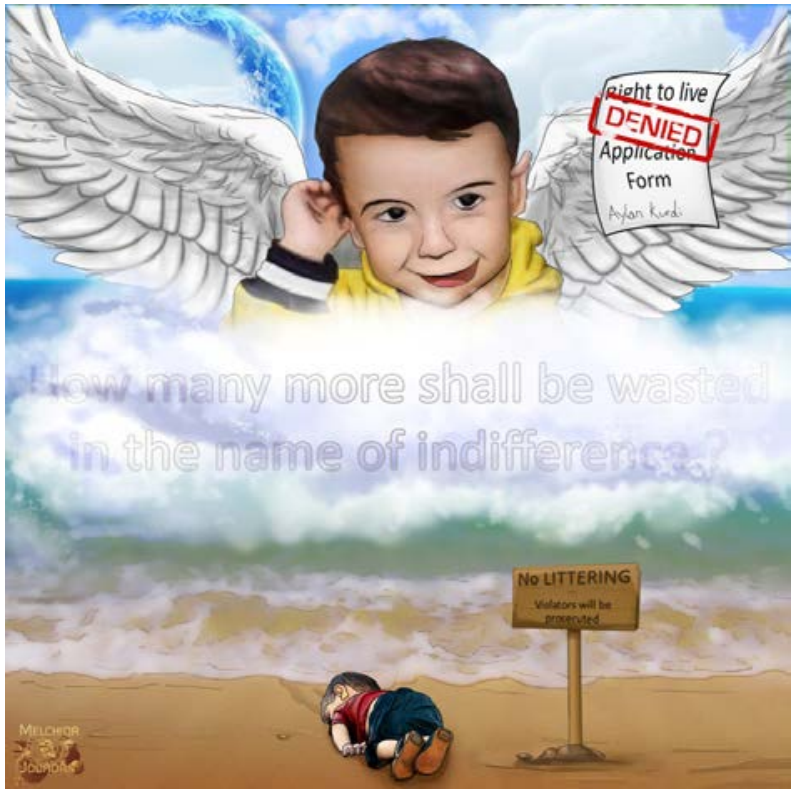

Il. 23. Retoryka pocieszenia: grafika autorstwa artysty o pseudonimie/nicku SuperSmurgger 


\section{ZAKOŃCZENIE}

„W łacińskim rdzeniu słowa protest jest wyraz testis, świadek - najpierw się pro-testuje, żeby móc zaświadczyć" 44 - pisał Paul Ricoeur. Temat dawania świadectwa w imieniu tych, którzy możliwości tej są pozbawieni, poruszył także Giorgio Agamben w swym traktacie Co zostaje z Auschwitz, gdzie pisał, iż jeżeli świadek „mówi jedynie w oparciu o niemożliwość mówienia, to dawane przezeń świadectwo nie może zostać zanegowane"\$5. Dając świadectwo, mówi on „Z upoważnienia” tego, który, umierając, zamilkł i nie może wypowiedzieć ani swojej niemożności mówienia, ani jej źródła. Jakkolwiek nieadekwatnie to nie zabrzmi, współczesny prosument, zderzony z fotografią autorstwa Nilüfer Demir, odpowiadając na nią, staje się takim właśnie testis, a jego testimonium, wyrażone językiem obrazu, zyskuje rangę protestu-świadectwa epoki Web 2.0: „Chcę sprawić, by jego [Aylana - przyp. P.J.] krzyk protestu [outcry] został usłyszany" - mówiła turecka fotoreporterka. Internauci, jak widzieliśmy, nad wyraz chętnie jej w tym pomagają i biorą na siebie ciężar dawania świadectwa krótkiego życia i przedwczesnej, tragicznej śmierci syryjskiego chłopca ${ }^{46}$.

44 Wydobywanie dobra. Z Paulem Ricoeurem rozmawia Brat Emil z Taizé, tłum. M. Prusak, „Więź” 2001, nr 12, s. 14.

45 G. Agamben, Co zostaje z Auschwitz. Archiwum i świadek (Homo Sacer III), tłum. S. Królak, Warszawa 2008, s. 165.

${ }^{46}$ Wierzę przy tym w szlachetność intencji ich twórców, tak jak wierzę deklaracjom Nilüfer Demir. Czy jednak krzyk protestu Aylana został usłyszany? Szczerze wątpię. Dwa miesiące przed śmiercią chłopca ówczesna premier polskiego rządu dokonała bazującego na kryterium religijnym podziału uchodźców na tych, którzy mogą liczyć na schronienie w Polsce, i tych, którzy nie (Aylan znalazłby się w gronie tych drugich). W dwa miesiące po jego śmierci opinia publiczna zwróciła uwagę na okrutne traktowanie uchodźców przez oficerów Frontexu na granicy macedońskiej dopiero po tym, jak sześciu mężczyzn zaszyło sobie usta w akcie protestu. Kiedy zaczynałem pisać ten tekst, dwie uciekające kobiety zmarły z zimna w lesie przy bułgarskiej granicy. Dwa dni wcześniej słyszałem, jak ponad tysięczny tłum zgromadzony na Placu Zamkowym w Warszawie śpiewał unisono „Wypierdalać z uchodźcami”, wymachując flagami w kolorze biało-czerwonym. $\mathrm{W}$ tym samym mniej więcej czasie w polskim internecie rozbudzona tak zwanym kryzysem uchodźczym wyobraźnia eksterminacyjna osiągnęła swoje apogeum. Przez parę wieczorów wraz z kilkoma osobami zbierałem komentarze (było ich 
Od kilku dni wsłuchiwałem się w głos Aylana Kurdiego docierający do mnie z dziesiątek obrazowych protestów-świadectw i kroiłem go na części za pomocą narzędzi semiotyka, które stopniowo tępiły się pod jego pluszami

łącznie ponad sześć tysięcy), w których wprost sugerowano rozwiązanie problemu z napływem uchodźców przez wskrzeszenie Hitlera, masowe egzekucje, uruchomienie komór gazowych i odpalenie na nowo krematoryjnych pieców. Te tysiące głosów, ziejących nienawiścią - czasem głupkowatą, czasem zadziwiająco na serio - wygłaszanych przez „ludzi takich, jak my” (na zdjęciach profilowych widniały uśmiechnięte kobiety, przystojni mężczý́ni, zakochane pary, rodziny z dziećmi, czasem... same dzieci), było dla czytającego, jak to określił Dariusz Czaja, „stężeniem trucizn na potężną skalę”. Od razu przyszły mi na myśl jego słowa, będące poniekąd „przesłaniem” płynącym z Lekcji ciemności: „Auschwitz wciąż tkwi w nas jako upiorna, ale realna możliwość. Skoro raz udało się to zrobić, to znaczy, że gdy zajdą stosowne okoliczności, będziemy umieli to zrobić jeszcze raz" (D. Czaja, Lekcje ciemności, Wołowiec 2009, s. 14 i 49). Pierwszego kwietnia 2016 roku Sejm w nowym składzie przyjął uchwałę, zapowiadaną wcześniej przez nową premier i ministra spraw zagranicznych (na marginesie: sprzeciw wobec przyjmowania uchodźców był jednym $\mathrm{z}$ ważnych punktów kampanii wyborczej zwycięskiej partii; na jednym ze spotkań jej prezes mówił o tym, że uchodźcy „przenoszą pasożyty i pierwotniaki”), zgodnie z którą „,wyraża zdecydowany sprzeciw wobec jakichkolwiek prób ustanawiania unijnych stałych mechanizmów alokacji uchodźców czy imigrantów" (http://orka.sejm.gov.pl/opinie8.nsf/nazwa/18_u/\$file/18_u.pdf [data dostępu: 10.11.16]). Po licznych obniżkach proponowanych kwot unijnych Polska ostatecznie nie zgodziła się na przyjęcie 400 (słownie: czterystu) osób uciekających $\mathrm{z}$ terenów objętych wojną i głodem. W dyskursie publicznym dominuje przedstawianie migrujących tłumów jako zagrożenia na wielu poziomach: ekonomicznym, kulturowym, cywilizacyjnym, zdrowotnym, a także źródła konkretnego niebezpieczeństwa dla życia obywateli (gwałty, przemoc, ataki terrorystyczne). Kwestia uchodźców uległa - jak to określa Zygmunt Bauman - „adiaforyzacji”, czyli wyłączenia z obszaru odpowiedzialności etycznej i przesunięcia w rewiry bezpieczeństwa publicznego (a więc Foucaultowskiej biopolityki). Reakcje na zdjęcie przedstawiające ciało Aylana Kurdiego są dobitnym przykładem tego, co polski socjolog określił mianem „karnawałów moralności” - „krótkotrwałych [...] wybuchów solidarności i troski, wywołanych przez kolejne medialne, spektakularne tragedie w niekończącej się sadze migracyjnej" (Z. Bauman, Obcy u naszych drzwi, tłum. W. Micner, Warszawa 2016, s. 90). W niespełna rok po śmierci Aylana Kurdiego ,ikoniczną" rangę zyskało zdjęcie kolejnego syryjskiego 
i puchami, pod tą materią miękką, gładką i pachnącą, aż w końcu nie mogłem już dłużej udawać, że nie mierzi mnie jego naiwna sentymentalność i dobrotliwość, jego pusta czułostkowość, jego ckliwość, jego absurdalna konsolacyjność, nieuprawniona baśniowość, jego tępa laurkowość i durnowata słodkość, że nie mierżą mnie na równi żywe kolory, jak i stonowane pastele, że nie mierzi mnie cała ta kreskówkowa czy bajeczna konwencja, niezależnie od stopnia talentu twórcy. Zadziwia lekkość tego ciała, dającego sobą do woli rozporządzać jako mała plamka na ekranie monitora.

Wpatruję się w obrazek, który skupia w sobie całą moją złość. Chłopiec w czerwonej koszulce znów leży na plaży, obok turecki policjant beznamiętnie spisuje raport, a z morza wychodzi cała wodna menażeria - krab, żółw, ośmiornica, delfin, rozgwiazda, wieloryb i jakaś pomniejsza ryba składają płetwy, odnóża, czy co tam też mają, w geście modlitwy i ronią obficie - bynajmniej nie krokodyle - łzy. Na innych obrazkach płaczą wraz z nimi misie, płacze księżyc, płacze jakaś niepokojąco dziwaczna wróżka, płacze cały świat. Odnoszę wrażenie, że przedstawienia te podpadają (łącznie $\mathrm{z}$ wpisanym $\mathrm{w}$ nie modelem oczekiwanej recepcji) pod Kunderowskie kryterium kiczu, czyli „drugą łzę” - łzę, którą roni osoba wzruszająca się swym własnym wzruszeniem. Z drugiej jednak strony czuję głęboki sprzeciw wobec własnego sprzeciwu. Czy w komunikacji opartej na przekazach wizualnych i skompresowanych komunikatach nastawionych na wywoływanie emocjonalnego rezonansu można wyrazić protest, nie popadając jednocześnie w kicz i rozrzewnienie? Nawet jeśli niektóre przykłady wskazują, że i owszem, można, to czy należy automatycznie dyskredytować te, którym to się nie udaje? Wszak pozostają one zaiste nielicznymi przejawami empatii i nawoływania do odpowiedzialności w świecie - wirtualnym i nie tylko - który chciałby raczej trzymać uchodźców w gettach, odgrodzić się od nich zbrojnymi murami, a nawet ich zgładzić...

chłopca - pięcioletniego Omrana Danqueesha, wydobytego przez ratowników z gruzów po bombardowaniu miejscowości Aleppo - zdezorientowanego, przestraszonego, pokrytego w całości pyłem i krwią. Była to okazja do kolejnego krótkotrwałego „karnawału moralności”, jak i wysypu internetowych remiksów (na paru zresztą odnaleźć można Omrana razem z Aylanem). 


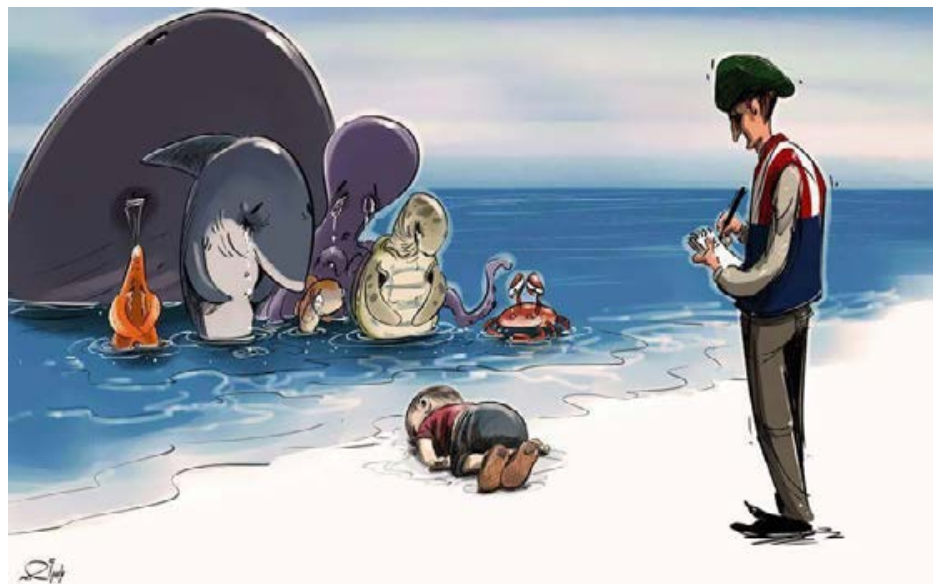

\section{Il. 24. Grafika autorstwa Azzama Daaboula}

W swoim cyklu fotografii z 2004 roku zatytułowanym Pozytywy Zbigniew Libera przedstawił „optymistyczne” wersje kilku ikonicznych zdjęć z wizualnego archiwum pamięci zbiorowej. Nie może dziwić, że cztery z pięciu prac przedstawiają trupy (Che Guevary ze zdjęcia Freddiego Alborty oraz rosyjskich żołnierzy poległych pod Stalingradem ze zdjęcia Dmitri Baltermantsa) i omal-nie-trupy (kadr z kroniki wyzwolenia obozu w Auschwitz oraz najsłynniejszą fotografię Nicka Uta). Na zdjęciach Libery argentyński rewolucjonista podnosi się z katafalku i odpala cygaro, ciała żołnierzy przeistaczają się w strudzonych biegaczy, którym nie udało się dotrzeć do mety wyścigu, więźniowie obozu uśmiechają się do nas zza zasieków sznurka do suszenia bielizny, tak jak i Kim Phúc, dość frywolnie biegnąca nago w towarzystwie spacerowiczów i spadochroniarzy. W jednym z wywiadów artysta dość prowokacyjnie stwierdził, iż „ludzie od prawdy wolą rzeczywistość pokolorowaną, więc postanowiłem dać im to, czego pragną. Świat dobry i poukładany, i pozytywny właśnie”. Interpretująca jego prace Ewa Domańska zauważa, że „można za ich pomocą pokazać, jak owe obrazowe toposy, reprodukowane w mediach, przeistaczają się w zbanalizowane obrazki, które nie wywierają już większego wrażenia; zostają niejako 
udomowione" ${ }^{\text {47. }}$. W kulturze konwergencji i remiksu ten zasygnalizowany przez Liberę i opisany przez Domańską dyskretny mechanizm - który warto byłoby poddać psychoanalitycznej lekturze ${ }^{48}$ - zyskuje swe potwierdzenie w pełni namacalne, spotęgowane i natychmiastowe. Nie potrzeba prowokacji sztuki krytycznej, by doświadczyć znanej skądinąd prawdy, że „Zanim zostaniemy zapomniani, przemieni się nas w kicz"49. Czy jednak ze zdania tego nie należałoby wyciągnąć wniosku, do którego skłania zarówno prowokacyjny cykl Libery, jak i przeprowadzona przeze mnie analiza taktyk wizualnych stosowanych w internetowych przeróbkach fotografii Aylana Kurdiego - a mianowicie, że kicz jest również wehikułem pamiętania; cłem, jakie płaci się za obecność w zbiorowej świadomości?

\section{Acknowledgements}

I wish to show appreciation for all of the artists who took Aylan Kurdi's tragedy into consideration and sought to shed light upon it. I express my thanks for their permission to reprint their works in my essay.

\section{Bibliografia}

Giorgio Agamben, Co zostaje z Auschwitz. Archiwum i świadek (Homo Sacer III), tłum. S. Królak, Sic!, Warszawa 2008.

Arjun Appadurai, Strach przed mniejszościami. Esej o geografii gniewu, tłum. M. Bucholc, PWN, Warszawa 2009.

Roland Barthes, Mitologie, tłum. A. Dziadek, KR, Warszawa 2000.

Roland Barthes, Światło obrazu, tłum. J. Trznadel, Aletheia, Warszawa 2008.

Zygmunt Bauman, Obcy u naszych drzwi, tłum. W. Micner, PWN, Warszawa 2016 Dariusz Czaja, Lekcje ciemności, Wydawnictwo „Czarne”, Wołowiec 2009.

Ewa Domańska, Historie niekonwencjonalne. Refleksja o przeszłości w nowej humanistyce, Wydawnictwo Naukowe UAM, Poznań 2006.

47 E. Domańska, Pamięć/przeciw-historia jako ideologia. „Pozytywy” Zbigniewa Libery, [w:] eadem, Historie niekonwencjonalne. Refleksja o przeszłości w nowej humanistyce, Poznań 2006, s 235 (wypowiedź Libery cytowana na stronie 236).

${ }_{48} \mathrm{Na}$ temat psychoanalizowania pamięci zbiorowej zob. W.G. Sebald, Wojna powietrzna i literatura, tłum. M. Łukasiewicz, Warszawa 2012.

49 M. Kundera, Nieznośna lekkość bytu, tłum. A. Holland, Warszawa 2001, s. 138. 
Andrzej Draguła, Flirt z sadyzmem? O fotografowaniu i ogladaniu okrucieństwa, „Więź” 2015, nr 2(660).

Piotr Jakubowski, O dobrej literaturze, „Zeszyty Naukowe Centrum Badań im. Edyty Stein” 2015, nr 13/14, Fenomen dobra, red. A. Grzegorczyk, P. Jakubowski.

Henry Jenkins, Kultura konwergencji. Zderzenie starych i nowych mediów, tłum.

M. Bernatowicz, M. Filiciak, Wydawnictwo Akademickie i Profesjonalne, Warszawa 2007.

Milan Kundera, Nieznośna lekkość bytu, tłum. A. Holland, PIW, Warszawa 2001. Audrey Linkman, Photography and Death, Reaktion Books, London 2011.

Wojciech Nowicki, Odbicie, Wydawnictwo „Czarne”, Wołowiec 2015.

W.G. Sebald, Wojna powietrzna i literatura, tłum. M. Łukasiewicz, W.A.B., Warszawa 2012.

Susan Sontag, Widok cudzego cierpienia, tłum. S. Magala, Karakter, Kraków 2010. Louis-Vincent Thomas, Trup. Od biologii do antropologii, tłum. K. Kocjan, Wydawnictwo Łódzkie, Łódź 1991.

Wydobywanie dobra. Z Paulem Ricoeurem rozmawia Brat Emil z Taizé, tłum.

M. Prusak, „Więź” 2001, nr 12.

\section{Źródła internetowe}

http://blogs.spectator.co.uk/2015/09/sharing-a-photo-of-the-dead-syrian-child-isnt-compassionate-its-narcissistic/

http:/grapevine.is/news/2016/03/15/lets-say-stop/

http://indiatoday.intoday.in/story/ai-weiwei-tribute-to-syrian-refugee-aylan-

-kurdi/1/587095.html

http://orka.sejm.gov.pl/opinie8.nsf/nazwa/18_u/\$file/18_u.pdf

http://m.chinadaily.com.cn/en/2015-09/08/content_21817372.htm

http://www.dailymail.co.uk/news/article-3227703/Thirty-people-recreate-death-

Alyan-Kurdi-laying-sand-Moroccan-beach-dressed-clothes-drownedSyrian-boy.html

https://anongalactic.com/syrian-boys-body-was-moved-before-photos-were-taken/ www.boredpanda.com/syrian-boy-drowned-mediterranean-tragedy-artists-respond-aylan-kurdi/?utm_source=facebook\&utm_medium=link\&utm_ campaign $=$ BPFacebook

www.nowilaymedowntosleep.org www.vice.com/read/nilfer-demir-interview-876 


\section{Źródła ilustracji}

il. 1. www.flickr.com/photos/syriafreedom/21076307990

il. 2.www.flickr.com/photos/136879256@N02/23354209300

il. 3. www.boredpanda.com/how-his-story-should-have-ended/

il. 4. www.boredpanda.com/faith-in-humanity-lost/

il. 5. www.boredpanda.com/from-embrace-of-syria-to-drowning-in-the-sea-turkey/

il. 6. www.lopinion.fr/sites/nb.com/files/2015/09/20150904_migrants_photo_choc. jpg

il. 7. www.boredpanda.com/god-be-with-you-little-angel-the-death-of-tragic-syrian-toddler-aylan-by-gunduz-aghayev/

il. 8. www.boredpanda.com/humanity-washed-ashore-4/

il. 9. http://indiatoday.intoday.in/story/ai-weiwei-tribute-to-syrian-refugee-aylan-kurdi/1/587095.html

il. 10. www.boredpanda.com/do-you-see-it-now/

il. 11. www.toonpool.com/cartoons/Ikonografie\%20des\%20Grauens_254493

il. 12. www.boredpanda.com/ring-a-ring-a-rosy/

il. 13. www.boredpanda.com/aylans-killer/

il. 14. www.boredpanda.com/still-the-same/

il. 15. www.boredpanda.com/humanity-slipping-away/

il. 16. www.boredpanda.com/a-better-place/

il. 17. www.boredpanda.com/foundling-child-by-ali-miraee/

il. 18. www.boredpanda.com/281427/

il. 19. http://omimic.deviantart.com/art/Aylan-Kurdi-tribute-560673023

il. 20. www.deviantart.com/art/Aylan-Kurdi-558363520

il. 21. www.boredpanda.com/faith-in-humanity-lost/

il. 22. www.boredpanda.com/in-the-arms-of-the-angel/

il. 23. http://supersmurgger.deviantart.com/art/No-Littering-Aylan-Kurdi-Tribute $-558195930$

il. 24. www.boredpanda.com/we-are-losing-ourselves-as-humansand-the-people-will-die-around-the-borders/

\section{The Unbearable Lightness of Consolation, the Unbearable Shallowness of Protest. Aylan Kurdi's Online Resurrections}

The aim of this article is to critically analyze the internet's remixes of Nilüfer Demir's photography showing the dead body of Aylan Kurdi - a 3-year old 
Syrian refugee - found on the beach near Turkish city Bordum. The main question here is: how the convergence culture 'regards the pain of the other' and deals with it? Semiotic analysis of chosen examples leads to a conclusion that while some artists undertake a specific visual tactics of protest and objection, more often, and even in clearly critical pictures, the 'rhetoric of consolation' is a predominating one and serves to both artists' and viewers' complacency and consoling. Terror of the pain and death is deleted from those images and replaced by cheap and idle tenderness or even kitsch.

Keywords: Aylan Kurdi, photography and death, migrant crisis, culture of convergence, political protest, remix, internet's art 